\title{
Régészeti kutatások Somogy megyében 2016-2017 között
}

\author{
HONTI SZILVIA ${ }^{1}$, M. ARADI CSILLA², BALOGH CSILLA ${ }^{3}$, FÜKÖH DÁNIEL ${ }^{4}$, \\ MOLNÁR ISTVÁN ${ }^{1}$, NÉMETH PÉTER GERGELY ${ }^{1}$, SOMOGYI KRISZTINA ${ }^{1}$, TOKAI ZITA ${ }^{5}$ \\ ${ }^{1}$ Rippl-Rónai Múzeum, H-7400, Kaposvár Fő u. 10., e-mail: somogyiregeszet@gmail.com \\ ${ }^{2}$ SMKH - KJH - Építésügyi és Örökségvédelmi Osztály, 7400 Kaposvár Nagy Imre tér 1., e-mail: csiaradi@freemail.hu \\ ${ }^{3}$ Istanbul University Research Institute of Turkology, TR 34080 Fatih-Istanbul, Horhor Cad. Kavalali sok. 5/4 \\ ${ }^{4} \mathrm{H}-1113$ Budapest, Nagyszőlős út 35., e-mail: dani.fukoh@gmail.com \\ ${ }^{5}$ Budavári Kft, H-1013 Budapest, Ybl Miklós tér 6. E-mail: zita.tokai@forsterkozpont.hu
}

Honti, Sz., M. Aradi, Cs., Balogh, Cs., FüKÖH, D., Molnár, I., NÉmETH, P. G. SOMOGYI, K. \& TOKAI, Z. M.: Archaeological research in Somogy county between 2016-2017.

Abstract: In the first half of the study excavation projects financed with the support of local governments and NKA (Bárdudvarnok, Iharos, Zamárdi) are described, in the second half the archeological results of the excavation connected to a development of Route No 67 and Route No 76 are related.

Keywords: Lengyel \& Balaton-Lasinja Culture circle foss, grave, Baden Culture biritual cemetery, Incrusted Pottery cemeterys, Premonstratensian Monastery, settlements from different ages

\section{Tervásatások: pályázati és önkormányzati támoga- tásból végzett feltárások}

\section{Bárdudvarnok - Barát-domb \\ M. Aradi Csilla és Molnár István}

Somogy megye egyetlen premontrei monostorának feltárását 2014-ban kezdtük meg, a 2014-2015. évi feltárások eredményeiről már beszámoltunk (HONTI ET AL. 2016 247-249, ARADI - MOLNÁR 2017). Feltártuk a nagyméretű, egyenes záródású szentélyü, három hajós, nyugati toronypáros prépostsági templomot és a benne lévő sírokat. Megállapítottuk, hogy az épületet később átépítették, a pilléreket tartó sávalapokat megerősítették, a főhajó nyugati harmadánál egy keresztirányú alapfalat találtunk. A munkát 2016-ban és 2017-ben a Nemzeti Kulturális Alap pályázatán nyert összegből folytattuk, a szükséges önrészt Bárdudvarnok Önkormányzata biztosította.

2016. október végén, november elején a prépostsági templom hiányzó, délnyugati részét tártuk fel (I. t. 1.). A templom északnyugati részén lévő falai és az északnyugati támpillérek erősen ki voltak szedve, az alapozásának alsó része maradt meg, 2014-es feltárás melletti, keleti részen viszont a felmenő fal alja is megőrződött. A pilléreket tartó északi sávalapozás hiányzó része is kibontásra került. Az északi torony keleti alapfala viszonylag jól megmaradt. Nem volt kötésben a templomfallal vagy a sávalappal, gyenge habarcsba rakott tégladarabokból épült közéjük, a torony alsó szintje nyitott volt a mellékhajóba. Az alapot később sírok rombolták.

A templomhajó nyugati részébe ásott fal hiányzó részét is kibontottuk, 2-3 rétegben ásott sírokat metsz, feltehetően már a 14. század végén, 15. században épülhetett (I. t. 2.). A korábbi időszakban a nyugati homlokzat sarkain voltak a tornyokat erősítő merőleges támpillérek, az átépítéskor a nyugati fal közepéhez is épült két nagyméretü $140 \mathrm{~cm}$ széles, $220 \mathrm{~cm}$ hosszú támpillér. Habarcsba falazott tégláikból sokat kiszedtek, de egyenesen záródó végükön (a hiányzó falba kötésböl) látszik, hogy később épültek a templom falához. A nyugati falat a belső oldalán is megerősítették, egy alapárokba tégladarabokat is tartalmazó rétegeket döngöltek. Készítésekor legalább két rétegben fekvő sírokat metszettek. Az említett munkálatok egyszerre történhettek, és egy nagy nyugati torony kialakításához kapcsolódhattak. A nagyméretű, négyzetes alakú, $5 \times 4,5$ méteres belterü torony a föhajó nyugati 2/5-ét elfoglalta. A délihez hasonlóan az északi sávalapot is egy mélyebb, de keskenyebb alapfallal szélesítették, amit a boltozáshoz kapcsolhatunk.

A templomban feltárt sírok száma 110-re nőtt, a délihez hasonlóan az északi mellékhajót és az ÉNy-i tornyot is használták temetkezési célra. A sírokat szakdolgozatához Mohácsi Mercédesz antropológus vizsgálta meg, a munkáját ezúttal is köszönjük. Megállapította, hogy a meghatározható csontmaradványok több mint 3/4-e (59) férfihez tartozott. A 18, azonosítható női sír sem egyenletesen oszlott el, a mellékhajókban és a tornyokban lévő kisszámú temetkezés között nagyjából a férfi sírokkal hasonló gyakorisággal fordultak elő, a főhajóban és föleg annak keleti felében jóval kisebb volt az arányuk. Feltételezhetjük, hogy a szerzetesek a templomba, elsősorban a főhajóba (kórusba?) temetkeztek.

A késői időszak külső járószintjét a templom körül, keletre és északra már korábban is sikerült azonosítanunk. Most a templom falai mellett, a szárazon rakott tégladarabokról kialakított járdaszerü felületen, egy kisebb foltban faszenes réteget és benne zsindelyszögeket, a leégett tetőszerkezet maradványait is megtaláltuk. Ez alatt a réteg alatt $20-30 \mathrm{~cm}$-rel egy korábbi külső járószint nyomát, egy ledöngölt mészporos réteget is feltártunk.

A feltárásra fordítható összeg maradékából, 2017. április 11. - 2017. május 02. között megkezdtük a prépostság épületeinek feltárását. A georadaros felmérés alapján ezeket a szentélytől keletre valószínűsíthettük, így itt nyitottuk szelvényeinket, összesen 7,5×13 m-es nagyságú területen. 

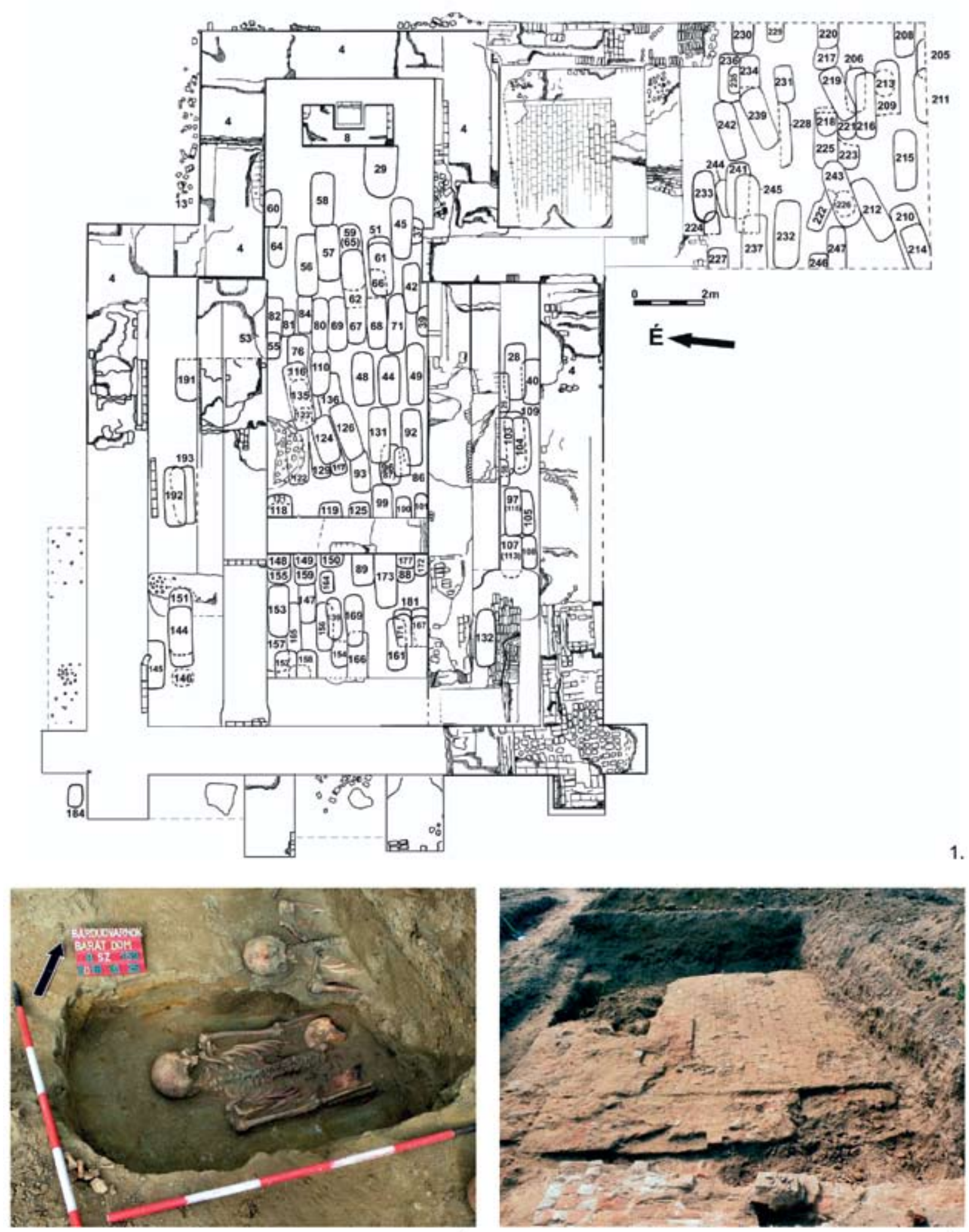

2.

3.

I. tábla. Bárdudvarnok - Barát-domb: 1. A 2014-2017 között folytatott feltárások összesítő térképe 2. A templom átépítésekor készített alapfal által rombolt sírok. 3. A sekrestye padlójának feltárt maradványai 
A templom szentélyéhez délröl csatlakozott egy $5,7 \times 7$ méter külső méretű helyiség, amelyet sekrestyeként azonosíthatunk. Északi és részben nyugati falául a templom falai szolgáltak, amihez keleten, délen, délnyugaton keskenyebb, 84-95 cm vastag falakat építettek, amelyek alapozása felül habarcsos téglasorokból, szélesebb alsó részén agyagba tett téglákból állt. A DK-i oldalán lévő támpillér valószínüleg evvel egyszerre épült, míg a DNy-i oldali később épült hozzá. Megtaláltuk kis területen a korai padlója nyomát is. A későbbi időszakban a sekrestye is új, kissé magasabban fekvő padlót kapott (I. t. 3.). Ez a templom késői időszaka padlójának felel meg, ugyanolyan habarcsba rakott téglasorokból áll, azzal egy magasságban van, de a téglái ellentétes, nyugat-keleti állásúak. Az újkorban a téglák többségét felszedték, csak 10-12 db maradt a helyén, de a többi lenyomata is látszik a szinte érintetlenül megmaradt habarcsétegben. A sekrestye korábbi belterénél kisebb felületet lefedő $285 \times 365 \mathrm{~cm}$ nagyságú padló és a sekrestye eredeti fala között keleten és délen egy alapfalat találtunk, amely a sekrestye késői időszakban történő megerősítésének, tatarozásának nyoma lehet. A sekrestye falai nem metszenek sírokat, de padlójának elbontásakor 2 nagy cölöplyukat találtunk, amelyek tengelye meröleges a templomra. Feltehetően egy korábbi, a sekrestyétől keskenyebb, faszerkezetes épület nyoma.

A sekrestyéhez újabb helyiség nem csatlakozott, tőle délre a georadaros felmérés is üres területet jelöl, a többi épület kissé DK-re helyezkedhetett el. A sekrestyétöl délre egy tipikus falusi temető 35 sírját tártuk fel. A keleti sávban főleg gyermeksírok voltak, 1-2 rétegben. Nyugat felé haladva 3-4 rétegben metszették egymást

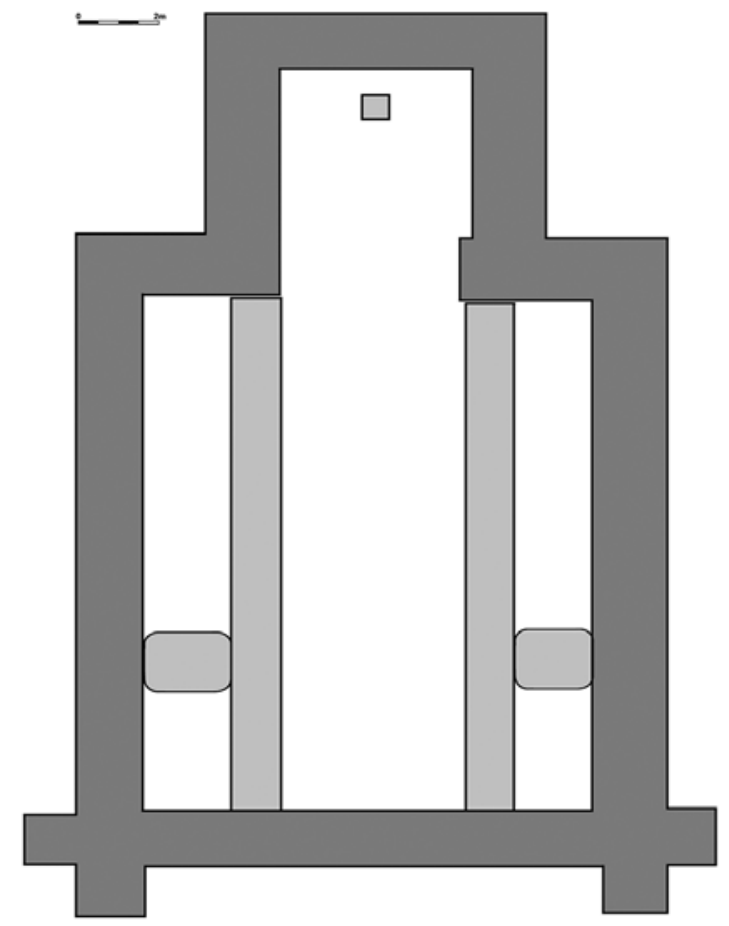

a temetkezések. A sírokban és szórványként pénzeket, gyürüket, ruha- és övcsatokat, párizsi kapcsokat, párta maradványait találtuk meg. Az egyik elhunyt feje alá, babonás szokásból egy kést tettek. A plébánosi funkciót is ellátó premontreiek temploma plébániatemplomként funkcionált. Feltehetően már a kezdetektől, de legkésőbb a 15. század első évtizedeiben már biztosan templom körüli temető müködött mellette, amely DK-en a templom és sekrestyéje illetve a többi prépostsági épület közötti területet is elfoglalta. A három ásatási évad restaurált leleteiből válogatást állítottunk össze (II. t. 1-9.).

Az eddigi feltárások alapján kirajzolódott a templom építéstörténete (1. ábra). 1252-től egy nagyméretű, egyenes szentélyzáródású, három hajós, támpillérekkel erősített nyugati toronypáros templom épült. A hajóinál 14,3 méter, a szentélyénél 8,5 méter széles épület teljes hossza a támpillérekkel 23,5-24 méter. Egy kisméretű oltáralapot és egy ledöngölt padlót kapcsolhatunk ehhez az időszakhoz. A legkorábbi időszakban még egy könnyü szerkezetü építmény lehetett a templom mellett, de viszonylag hamar megépült a sekrestyéje. A prépostság többi épülete kissé távolabb állhatott.

Leghamarabb a 14. század közepén-végén a templomot átépítették. Egy nagyobb nyugati tornyot építettek, ehhez a templomhajó nyugati részét egy alapfallal leválasztották, míg a nyugati homlokzatát masszív támpillérekkel erősítették meg. A korai templom padlószintjét valószínűleg a nyugati rész átépítésekor egy időben megemelték, egy ledöngölt rétegre, féltéglákból, nagyobb tégladarabokból, szárazon, új padlót raktak. Egy nagy $U$ alakú oltár és egy belső szószék is készült.

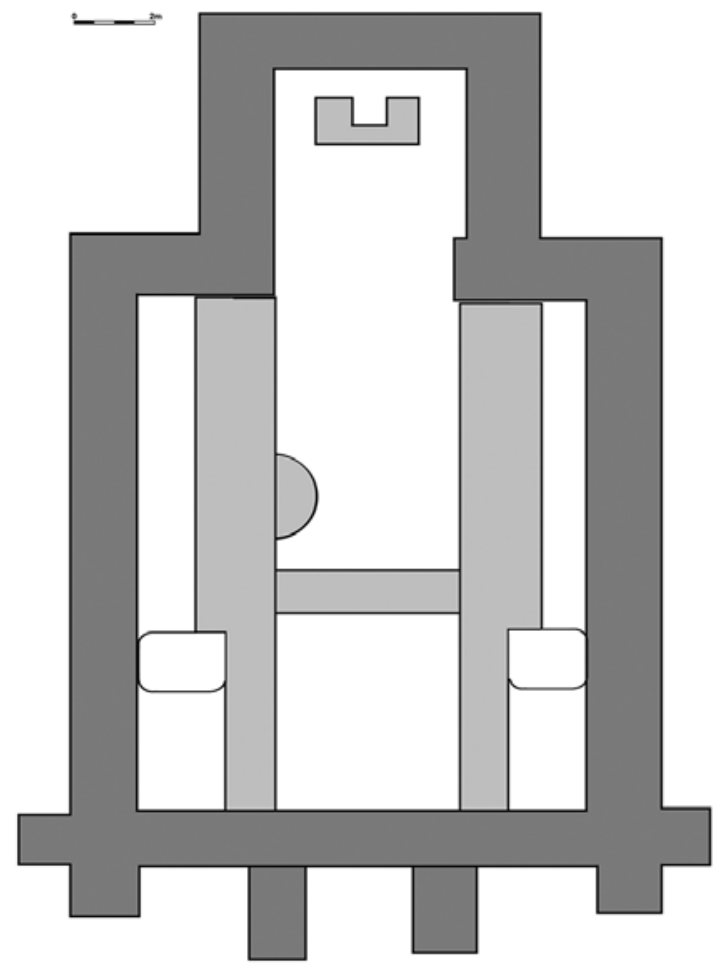

1. ábra. A prépostsági templom korai és átépités utáni alaprajza 
A monostor életének késői időszakában a prépostságban tűz pusztíthatott, így a templom felújításra szorult. Az addigi padlószint maradványaira egy feltöltési réteg került, amiben égett csontdarabok mellett, bronzolvadékokat, égett harangdarabokat találtunk (II. tábla 10-11.). Az ezen kialakított habarcssávra párhuzamos, észak-déli irányú téglasorokat helyeztek. A sekrestye is újabb padlót kapott, ráadásul belül megvastagították falait is.

A templom török-kori pusztulásáról az utolsó padlót áttörő faldarabok, a templom leégett tetejének a templom mellett talált maradványai, egy újabb harang megégett töredékei tanúskodnak. A területre még a prépostság pusztulása után is temetkeztek, az épületek maradványait jórészt a 18-19. században építőanyagnak hordták el.

A feltáráson a kaposvári Rippl-Rónai Múzeum dolgozói közül részt vett: Molnár István, Nyári Zsolt, Cserép Tamás, Stunya Péter, Papp Zoltán.

\section{Zamárdi - Réti földek Balogh Csilla}

2016-ban és 2017-ben is folytattuk a Zamárdi - Réti földek lelőhelyen (lelőhelyazonosító: 20408) húzódó, nagy kiterjedésü, avar kori temető északnyugati, beépítetlen részének kutatását. A kutatott terület a 2015-ben megnyitott szelvényünk folytatása, annak észak és kelet felé történő bővítése, mely három telket érintett (hrsz. 2495/7, 2493/6, 2492/5). 2016-ban egy, míg 2017-ben két alkalommal végeztünk feltárást, összesen $840 \mathrm{~m}^{2}$ területen 102 sír került elő.

A feltárt temetőrész használata a 7. század harmadik harmadától a 8. század közepe tájáig keltezhető. A korábbi, 7. század végi temetkezésekben vésett-poncolt fonatos díszű, lemezes övdíszek (ún. trasszírozott veretek) és összetett hátveretekkel díszített övek maradványai kerültek elő. Feltűnő volt e sírokban, az egyébként a temető egészére jellemző, öntött bronz korongok, illetve a koporsóvasalatok teljes hiánya, s a használati eszközök elenyésző számú előfordulása. A sírok aljában sem tapasztaltuk a másutt általánosnak mondható beásásokat. Ugyanakkor e sírok nagyságrendekkel nagyobb méretűek voltak, mint a temetőrész más sírjai, egyes sírok mélysége a nyesett felszíntől elérte a 2,5-2,7 métert.

Az északi szélső sírok megásására a 8. században kerülhetett sor. Erről tanúskodnak a férfi sírok öntött, indás övszerelékei, valamint a női sírokból előkerült Osztopán-típusú felhúzott lemezgömbös fülbevalók. Megfigyeléseink szerint ezeket nem fülben viselték, hanem a homlokon körbefutó, 3-6 cm széles homlokpántba, fátyolt leszorító pántba voltak beakasztva, a halántéknál. A két „fülbevaló” között apró köles méretű gyöngysorok kerültek elő, egyes esetekben a koponya alól, más esetekben a mellkasról. Ezek a megfigyeléseink lehetőséget nyújtanak az ékszertípus viseletének új rekonstrukciójára.
A temető északi szélén előkerült sírok közös jellegzetessége volt, hogy a sírok szokatlanul keskenyek, azonban nagyon mélyek voltak, a felnőtt egyének sírjának átlagos mélysége 1,7-1,9 méter között változott. Valamennyi sírgödör esetében megfigyeltük a rövidebb oldalak mentén a sír aljában kialakított gödröket, melyek többnyire téglalap alakúak és változó mélységűek $(7-25 \mathrm{~cm})$ voltak. A gödrök fala a sír oldalaihoz illeszkedő oldalakon meröleges volt, azonban a sírgödör felé eső oldalnál következetesen rézsűs kialakításra törekedtek. A férfivázak esetében számos esetben az újcsontképződés és az izomtapadási felületek rendkívüli mértékű megerősödése hosszan tartó, komoly fizikai igénybevételről, megerőltető munkáról árulkodik.

A közép avar kor végén - a késő avar korban használt temetőrész déli felébe egy kb. 50 sírból álló, korábbi, a 7. század középső harmadára keltezhető sírcsoport ékelődött be. E sírcsoportban öt ló-lovas sírpár került elő, ezek a sírcsoport közepén helyezkedtek el.

A nagyméretü, igen mély aknasírokban öves férfiak nyugodtak, temetkezéseik bolygatottak, raboltak voltak. Sírjaikban nemcsak a deszkakoporsó maradványa jelentkezett, hanem fa sírkamra nyomait is megfigyeltük. E sírokból ezüst pitykék, illetve II. germán állatstílusú szalagfonattal díszített veretek kerültek elő.

A sírok hossztengelyével egyvonalban, az ember-sírok láb felöli végénél, kisebb és sekélyebb, téglalap alakú gödrökben, lábukra rogyasztott helyzetben feküdtek a felszerszámozott lovak, az embervázakkal ellentétes helyzetben. Az egyik gödörben két, párhuzamosan fektetett lóváz került elő (2576. sír). Három lósír esetében a gödrök sarkában cölöpnyomok mélyedtek le, melyek sírépítmény alkalmazására utalnak.

Külön említésre érdemes az 2593. lósír, melyben a hosszú akna aljába kialakított sekélyebb gödörbe szinte belegyömöszölték a lovat (III. tábla 1.). Ebben és a 2589. lósírban is a ló feje előtt egy kisebb, teknős gödör mélyedt a sír aljába, amelyeknek sötétbarna-fekete, zsíros betöltése szerves anyag egykori jelenlétére utalt. A gödrökben, körben lószerszámvereteket találtunk. Ezekbe a kis gödrökbe beletekerve külön helyezték el a fejkantárt (III. tábla 3.), a farhámra utaló leletek a lóvázakon kerültek elő (IIII. tábla 2.).

A lósírokból származó veretek között ezüst rozetták, aranyozott ezüst és aranyozott bronz, kőbetétes veretek, valamint II. germán állatstílussal díszített szíjvégek találhatók. A lószerszám egyéb tartozékai (oldalpálcás zabla, hevedercsatok és karikák, kengyelek) mellett, a lókoponyák mellöl, egy-egy lándzsa került elő, illetve néhány esetben a bordákon nyílcsúcsokkal teli tegezés íj maradványát találtuk.

A ló-lovas sírpárok környékén olyan férfisírok kerültek elő, melyek mindegyikében egy-egy vas nyílhegy volt. A női és gyermeksírokban kerámiaedények voltak, melyek a sírok koponya felöli sarkában, a temetkezések, illetve a koporsók jelentkezési szintje fölött kerültek elő. Helyzetük és a környezetükben megfigyelt, kevert betöltés arra utal, hogy az edényeket valószínüleg utólag ásták bele a sír sarkába. 


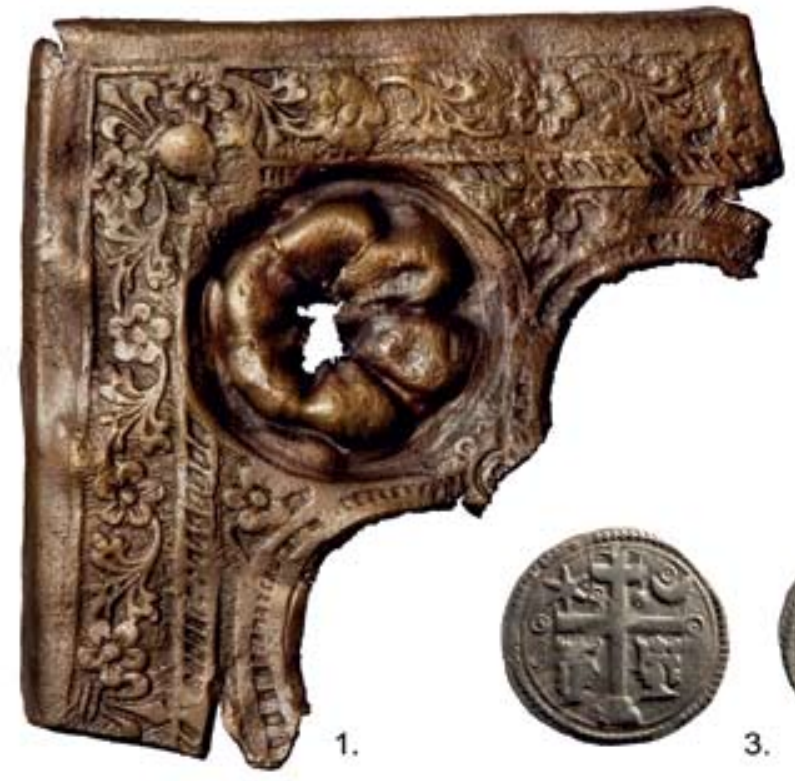

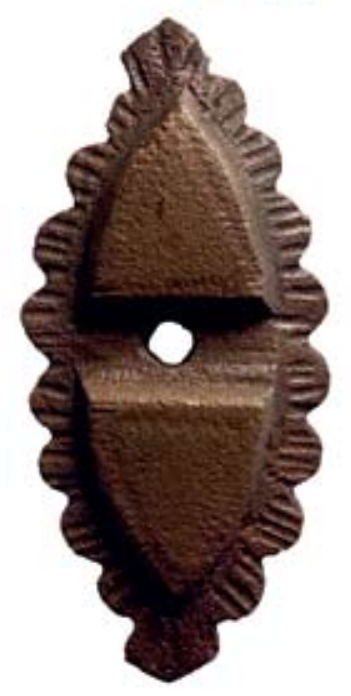

4.

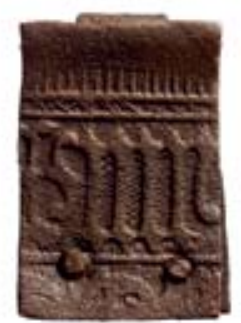

7.

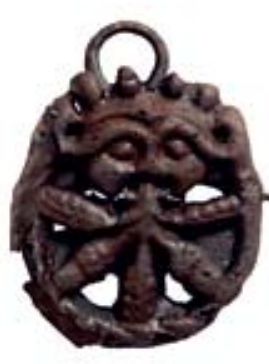

5.

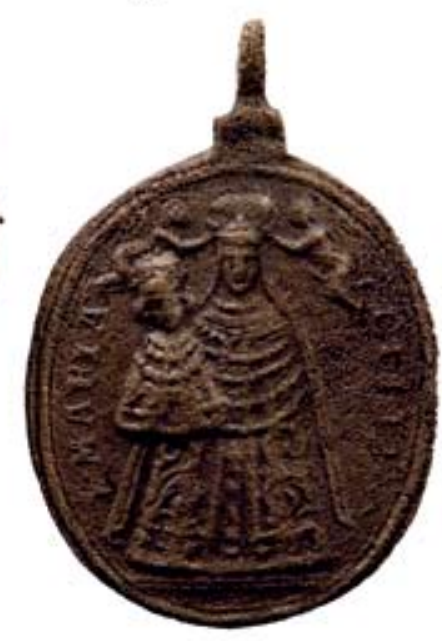

6.

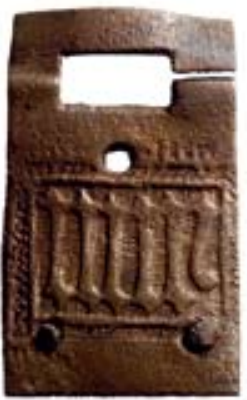

8.

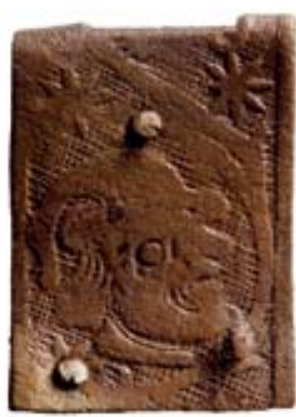

9.

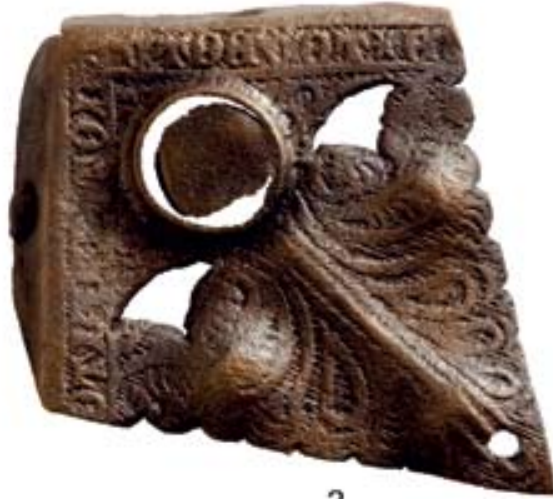

2.
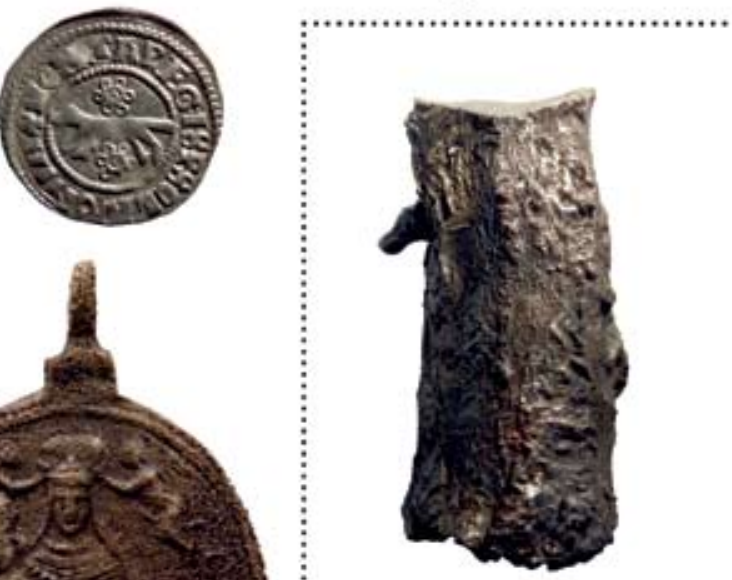

10.

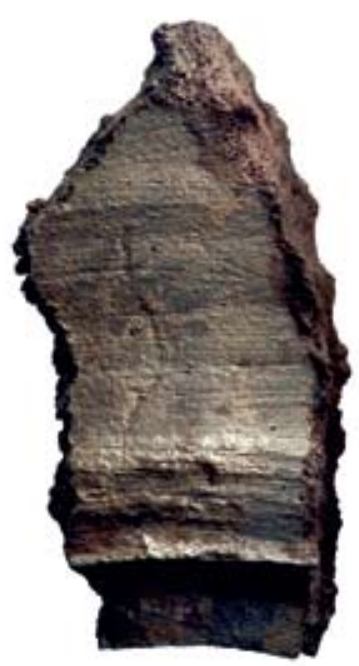

11.

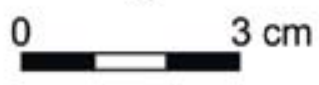

II. tábla. A bárdudvarnoki premontrei prépostság feltárásakor talált középkori leletek: 1-2., 7-9. könyvveretek és könyvcsatok, 3. szlavón dénár, 4. veret, 5. ruhakapocs, 6. újkori kegyérem, 10-11. harang darabjai 

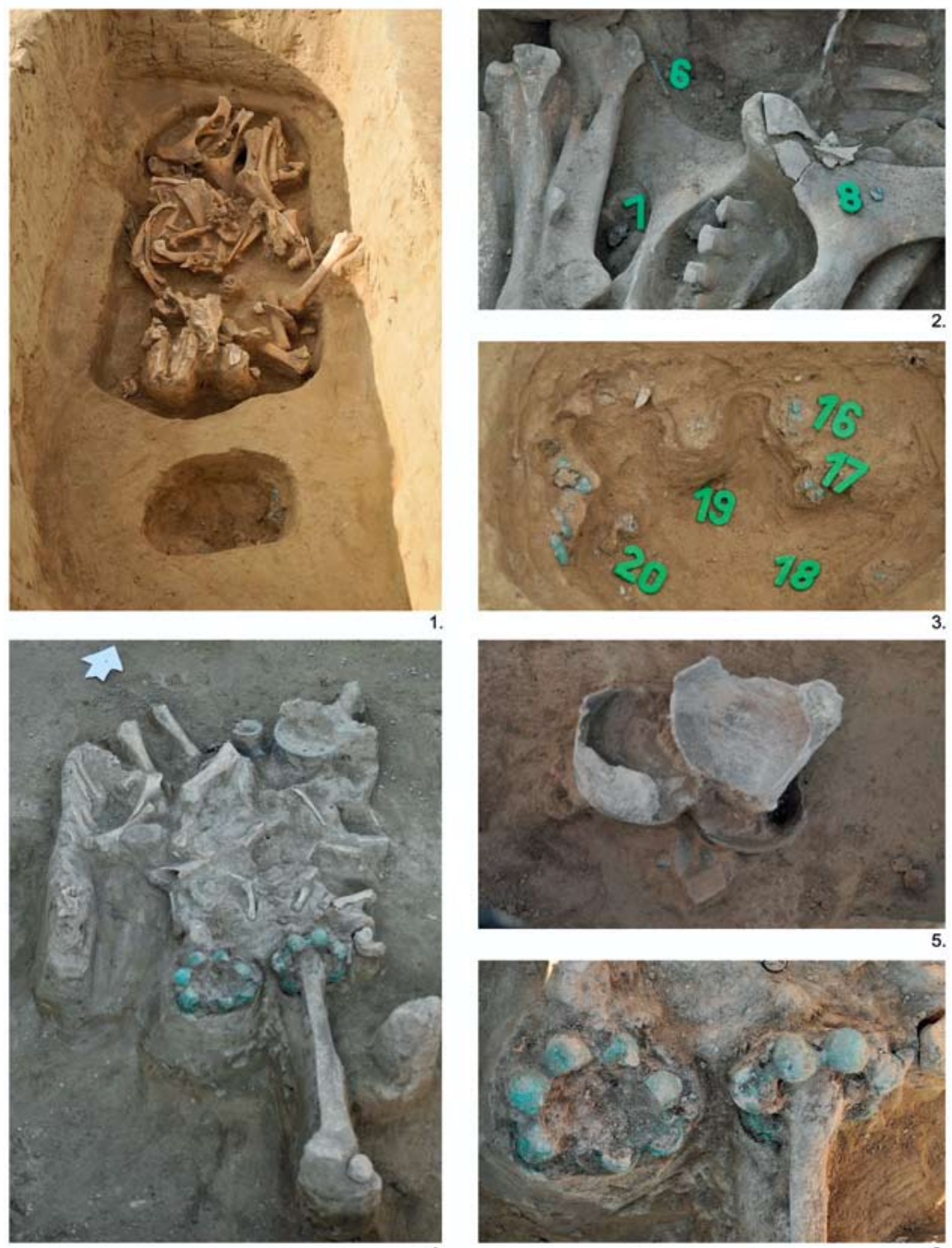

5.

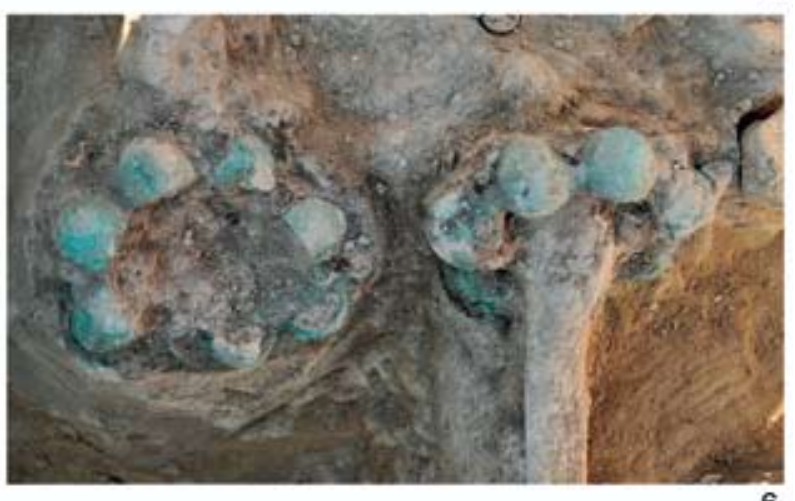

III. tábla. Zamárdi - Réti földek. 1. 2593. lósír 2-3.

A lószerszámok elhelyezése 4-6. A 2614. számú kelta sír 
A korábbi évek megfigyeléseivel ellentétben ezen a területen viszonylag kevés volt a bolygatott sírok aránya, főként a lovakhoz tartozó férfi sírok esetében volt jellemző a nagymértékű bolygatás. A kutatott felületen nem került elő egyetlen olyan üres, sekély gödör sem, amilyet a 2015. évi feltárás során nagyobb számban találtunk, melyeket a sírrablással hoztunk összefüggésbe, a sírok felderítésére szolgáló kutatógödörként értelmezve.

A temető északi szélénél előkerült a 2380. számú, többszörösen megújított árok újabb szakasza, mely mellett két sekély, keskeny kísérő árokszakasz is jelentkezett. $A z$ árok vágott három sírt, vagyis itt az árok megásására a sírok megásását követően került sor ellentétben a tavalyi megfigyeléseinkkel, ahol az árok korábbinak bizonyult a beleásott síroknál.

Az avar kori sírok alatt előkerült egy kelta sír maradványa (2614. sír), melyet valószínüleg már az avar sírok kirablása során megbolygattak, ekkor már kiemeltek két edényt a sírból, amelyek a sír rablógödrében feküdtek (III. tábla 5.). A sírban egy nő csontváz maradványa feküdt, in situ helyzetben csak a jobb lábszárcsont és a lábfejcsontok maradtak meg (III. tábla 4.). A bokáknál öntött bronz lábperecek kerültek elö (III. tábla 6.). A jobb lábfej végében két edény állt, a bal lábfejen egy fél disznó váza hevert.

A továbbra is tanásatás keretében folyó kutatási program a Zamárdi Önkormányzat támogatásával a Pázmány Péter Katolikus Egyetem Régészettudományi Intézetének és az İsztambul Egyetem Turkologiai Kutatóintézetének közös kutatási projektje. A feltáráson az intézet hallgatói mellett lengyel régészhallgatók vettek részt.

\section{„A 67-es út 2×2 sávos fejlesztése” projekthez kap- csolódó régészeti munkák}

A 67-es számú út Kaposfüred és Somogytúr közötti szakaszához kapcsolódó régészeti munkák 2016-2017 során is folytatódtak. A $2 \times 2$ sávosra tervezett út végleges nyomvonalán 2016 februárjában a Budavári Kft. által végzett terepbejárás során újabb településnyomok váltak ismertté, így a tervezett út $33,2 \mathrm{~km}$ hosszú szakaszán immár 51 régészeti lelőhely fekszik.

$\mathrm{Az}$ út által érintett terület domborzati képét a Vadépuszta határában eredő két patak - az északi irányba, a Balatonba folyó Tetves-patak és a déli irányba, a Kaposba torkolló Orci-patak - völgye, és a mellettük futó dombvonulatok határozzák meg. A völgyet szegélyező dombhátak enyhe lankái az őskortól a török időkig lakottak volt, sok településnyom és néhány temető, valamint nagy mennyiségü leletanyag tanúskodik ezekről. A délebbi szakaszon az út elkanyarodik az Orci-pataktól, és a Deseda-patak - Varga-bonyi-árok által kialakított mély völgyeket keresztezve csatlakozik a korábban megépített útszakaszba.

A projekthez kapcsolódó próba- és teljes felületű feltárásokat a Rippl-Rónai Múzeum mellett a Móra Ferenc Múzeum, valamint korábban a Forster Központ, az Ásatárs Kft., a Lekri Group Kft. és a Salisbury Kft. munkatársai folytatták, a szakmai koordinációt a Budavári Kft. végezte.
Alább a Rippl-Rónai Múzeum által feltárt lelőhelyeket délröl északra vesszük sorba, ahogyan az út kilométer-szelvényei is haladnak.

\section{Kaposvár - Kaposfüred-Hetes-Tábla (77303) Molnár István}

A lelöhely a Kaposvárt Magyaregressel összekötő főút két oldalán található, nyugatról egy, a Varga-bonyiárokba futó kis vízfolyás határolja. Tőle délre a 77305. számú lelőhely található.

A 2016. évi próbafeltárás során $548 \mathrm{~m}^{2}$ nagyságú területet humuszoltunk le, és 42 jelenséget különítettünk el. A feltárt objektumok jó része újkőkori és rézkori: a Dunántúli Vonaldíszes Kerámia-, a Lengyeli- és a bolerázi-badeni kultúrák időszakába tartozó gödröket bontottunk ki. Két késő rézkori, dél-északi tájolású, zsugorított temetkezést is feltártunk. Az egyik elhunyt mellé három edényt is eltemettek, míg a másikban csak egy csigagyöngyöt találtunk. Egy gödör bronzkorinak, egy épület, egy tüzelőberendezés és 3 gödör Árpád-korinak bizonyult. ${ }^{1}$

A feltárás munkatársai: Molnár István régész, Nyári Zsolt, Stunya Péter, Cserép Tamás technikusok.

\section{Kaposvár - Egresi út 2. lelőhely (77305) \\ Molnár István és Somogyi Krisztina}

A lelőhely a Kaposvárt Magyaregressel összekötő út két oldalán található, nyugatra egy, a Varga-bonyiárokba futó kis vízfolyás határolja. 2016 novemberében próbafeltárást, egy évre rá megelőző feltárást végeztünk a lelőhelyen. Eredetileg a lelőhely nyomvonalba eső részének csak egy része volt feltárásra kijelölve, de a magasan jelentkező, nagyszámú objektum miatt a tervezettnél nagyobb felületet $\left(15051 \mathrm{~m}^{2}\right)$ nyitottunk meg.

A lelöhelyen összesen 235 bontási egységet különítettünk el. A legidősebb objektum egy Lengyeli kultúrába tartozó gödör volt. A legtöbb objektum a Badeni kultúra időszakába tartozott, közel negyven gödör mellett egy nagyméretű objektumkomplexum és 4 tüzelöberendezés. Gazdag leletanyagot, nagyszámú edénytöredéket találtunk. A 6 zsugorított csontvázas temetkezést részben megbolygatta a szántás. A jó állapotban megmaradt sírokban sem volt melléklet. Rítusuk alapján őskori temetőhöz tartozhatnak, amelynek sekélyebb sírjai megsemmisültek.

Kora- (Somogyvár-Vinkovci-kultúra) és késő bronzkori gödröket is feltártunk. A 107. számú kisméretü, későbronzkori gödörben, feltehetően egy nagyobb méretü edényben, 3 bronz öntölepényt találtunk (IV. t. 1-2.). A nagy mennyiségü kerámiaanyagból csak a restaurálás után dönthető el, hogy mekkora mennyiségü a töredékanyag (sok edény alig illeszthető töredékei), vagy egy együttesröl, több edény szándékos deponálásáról

1 A lelöhely megelőző feltárását 2018-ban végeztük, ekkor DVK Lengyeli, Badeni telep mellett a Balaton-Lasinja-kultúra és a Somogyvár-Vinkovci-kultúra objektumait is megtaláltuk. Római település és egy langobard temetőrészlet is feltárásra került, az objektumok többsége pedig egy nagy kiterjedésü Árpád-kori telephez tartozott. 
van szó. Egy ilyen típusú együttes, mely edényekből és bronzokból áll, különlegesség a Somogy megyei késő bronzkorban.

29 jelenség egy kora Árpád-kori településhez tartozott. A gödrök, cölöplyukak mellett két félig földbe mélyített épületet, három külső kemencét is feltártunk. A rézkori, kora bronzkori és Árpád-kori település észak felé, a szomszédos 77303. számú lelőhelyen folytatódott.

A feltárás munkatársai: Molnár István feltárás vezető régész, Somogyi Krisztina, régész, Nyári Zsolt, Stunya Péter, Balla Krisztián, Cserép Tamás technikusok

\section{Magyaregres - Macskalyuk (77317) Molnár István}

A Magyaregres külterületén fekvő lelőhelyen, 2017. március 7-20. között, összesen $13588 \mathrm{~m}^{2}$ nagyságú területet nyitottunk meg, amelyböl $10267 \mathrm{~m}^{2}$ pozitívnak bizonyult. Itt, Magyaregresen, a lelöhelyek a Desedapatak és a Varga-bonyi-árok két oldalán sürüsödnek. A két vízfolyás egy viszonylag meredek oldalú lapos tetejü dombot fog közre, a mi feltárási területünk a Deseda-patakra néző lejtőn fekszik.

A 145 bontási egység nagy többsége a BalatonLasinja-kultúra időszakába volt sorolható, egy nagykiterjedésü telep keleti részét alkották. A telep központja a mi területünktől nyugatra volt, a Magyaregres-Vargabonyi-ároktól keletre nevű lelőhelyen, melyet egy évvel korábban a Lekri Group tárt fel. Sajnos ezek a rézkori objektumok nagyon leletszegények voltak, de jellegük, betöltésük egyértelmüen a Lasinja telephez kötik. Hét keskeny, mély, árokszerü objektumot találtunk, ezek általában párosával fordulnak elő, valamilyen építmény részei lehetnek. A gödrökön kívül nagyobb számú cölöplyukat is találtunk, ezek néhol rendszert alkotnak, egy 15×12 méteres cölöpszerkezetű épületet jelölnek ki.

A lelőhely keleti, mélyen fekvő részén kelta objektumok vannak. Sajnos ezek egy része a talajvíz szintje alatt volt, de így is több gödröt, cölöplyukat, egy négyzetes alakú épületet és egy kemencét is feltártunk. Ezen a részen egy Árpád-kori gödröt is találtunk. A lelöhely középső és keleti részén hosszú, de viszonylag sekély árkok voltak, ezek valamilyen rendszert alkotnak, párhuzamosak és keresztirányúak is vannak. Késő középkoriak, kerámia és vastárgyak (szögek, csat) kerültek elő a betöltésükböl. Talán valamilyen karámrendszert adnak ki.

A feltárás munkatársai: Molnár István régész, Nyári Zsolt, Stunya Péter, Cserép Tamás technikusok.

\section{Mernye - Irtások (91199) Molnár István}

A lelöhely Mernyétöl délnyugatra, a jelenlegi 67-es úttól nyugatra található. A feltárási felület egy kisebb déli, és egy nagyobb, északi felületre oszlott. A déli felület üresnek bizonyult, az északi felület középső részén nagyjából egy csoportban helyezkedtek el a középső rézkori Balaton-Lasinja-kultúra objektumai.
A feltárást 2016. november 15. és 22. között végeztük. Összesen 13 bontási egységet különítettünk el, gödrök mellett egy nagyméretű rézkori agyagnyerőt tártunk fel. Utóbbit egy agyaglencsébe ásták, a kitermelés után hulladékkal töltődött fel, így viszonylag gazdag leletanyagot tartalmazott.

A feltárás munkatársai: Molnár István régész, Nyári Zsolt, Stunya Péter, Cserép Tamás technikusok

\section{Gamás - Vadépusztai-mező 1. (72167) \\ Molnár István és Somogyi Krisztina}

A lelőhely a Gamáshoz tartozó Vadépusztától délre, Kisbabapusztától északra helyezkedik el, az Orci-patak völgye mentén, attól nyugatra, hosszan elterülö vonulaton, amit egy, a patakba torkolló, Ny-K-i folyásirányú, kis időszakos vízfolyás tagol. Ez a völgy a lelőhely legmélyebb pontja, az ettől északra és délre lévő dombok oldalán és platóhoz közeli részén lévő, magasabb területekre terjed ki.

2015-ben próbafeltárást (HONTI ET AL 2016. 264.), majd 2017-ben két ütemben, szeptemberben és októberben megelőző feltárást végeztünk a lelőhelyen. Először a mai 67-es úttól nyugatra lévő területen dolgoztunk. A lelőhely teljes hosszában nyitottunk egy sávot, de csak ott bővítettünk a teljes szélességre, ahol objektumokat találtunk. A munka második szakaszában a mai 67-es úttól keletre lévő területet humuszolták le. A felső, szántott réteg leszedése után csak további $30 \mathrm{~cm}$ mélyen szedhettük a tükörfelületet. A lelőhely északi részének déli végét nem nyitottuk meg, mivel ebben a mélységben még nem jelentkeztek az objektumok.

A lelöhelyen 18989 m²$^{2}$ en 353 bontási egységet különítettünk el. A legkorábbi objektumok a Dunántúli Vonaldíszes Kerámia gazdag és értékes leletanyagot tartalmazó gödrei voltak. Ez a középső neolitikus telep az Orci-patak völgyére hajló domb lejtőjén sűrűsödött, a domb magasabb részére (a 67 . föút nyugati oldalára) szórtan terjedt ki. A fent említett, Ny-K-i irányú időszakos vízfolyás völgye határolja déli irányban.

$E$ völgytől délre koncentrálódott a középső rézkori Balaton-Lasinja kultúra települése, amely számos gödörből állt. A telepen belül feltártunk egy ovális körvonalú árkot, amelynek hiátusai átjárók lehetettek, az egyik átjárónál 2 jellegzetes ún. Spitzgraben (rövid, „V” átmetszetü árokszerü beásás) helyezkedett el (kapuszerkezet lemélyítése?). (IV. t. 7.) Feltehetően a települést kerítő árok lehetett egy szintén nagyjából „V” keresztmetszetü, a szelvényen keresztül futó árokív, amelynek folytatását a mai főút építése során pusztíthatták el. A telep ÉÉNy felé esetleg a vonulat magasabb részére is kiterjed, mivel a főúttól Ny-ra 2017-ben előkerült egy Balaton-Lasinja-korú gödör.

A késő rézkori Baden-kultúra időszakába számos gazdag leletanyagot tartalmazó gödör és három kemence tartozott. A telep szórtan, de hosszan nyúlik el a patakvölgy mentén a 67 . föúttól K-re, mindegyik felületen megtalálható volt. 

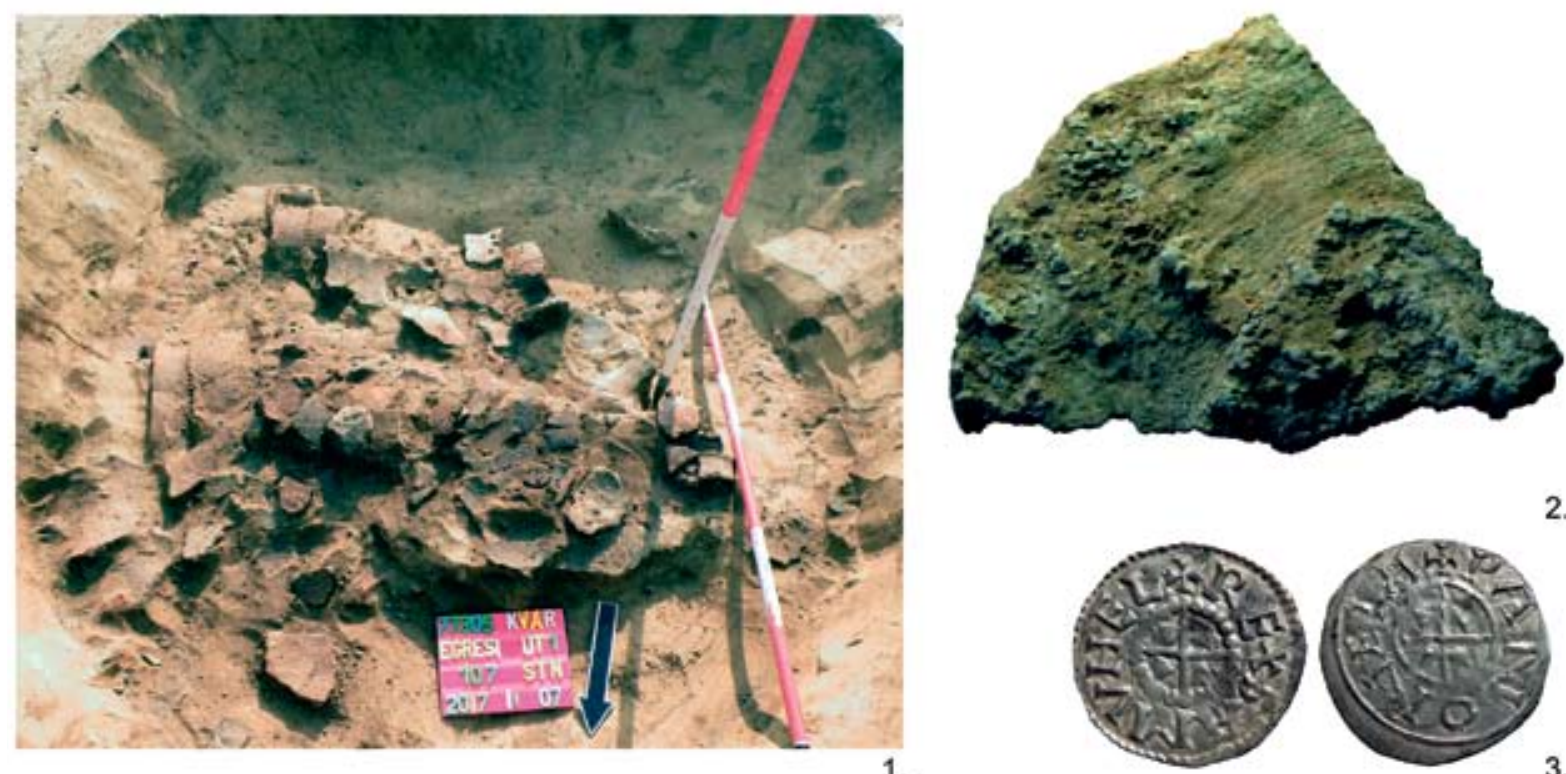

3.
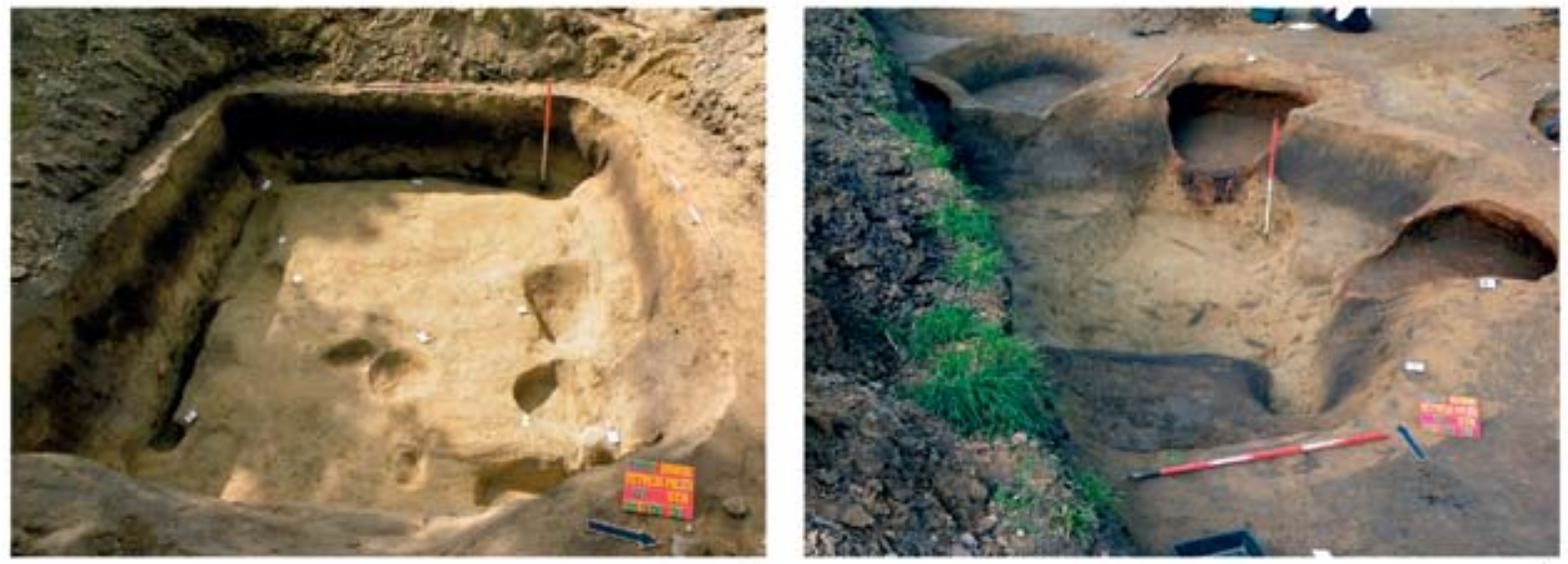

4.

5.
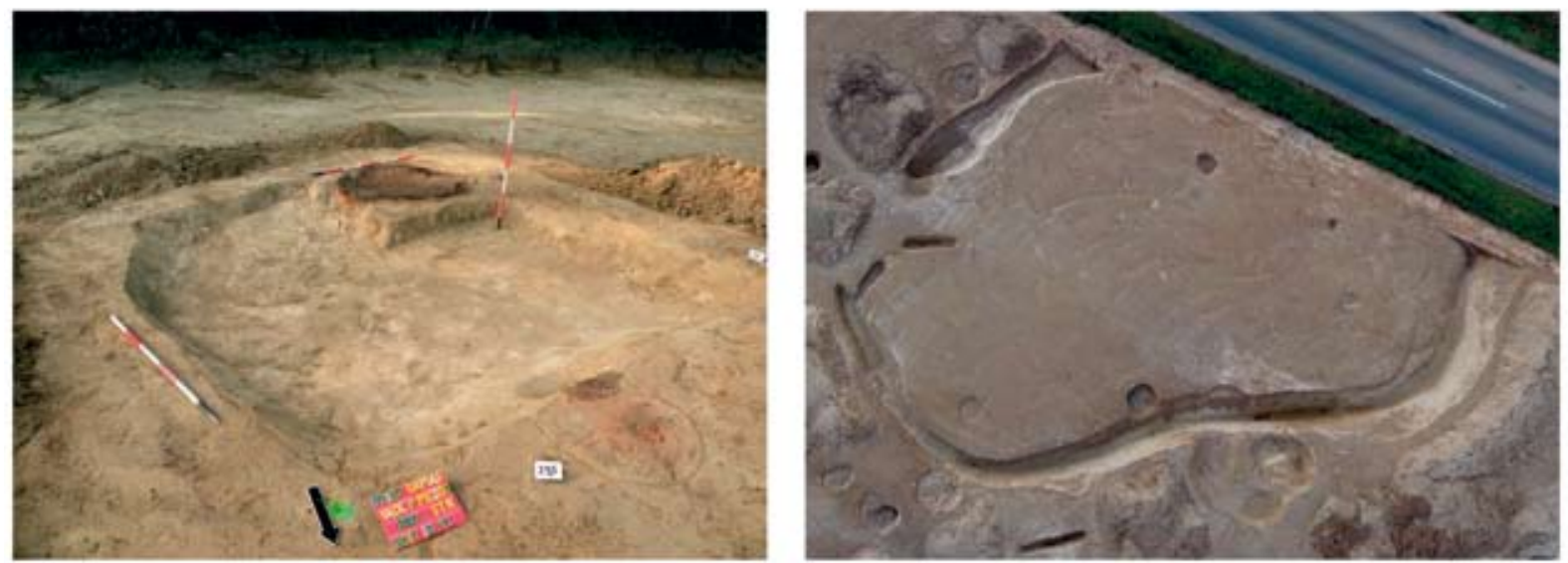

6.

7.

IV. tábla. 1-2. Kaposvár - Egresi út 2: A 107. objektum, és az egyik bronz öntölepény. 3-5. SomogybabodTetvesi-mező: 3. Aba Sámuel pénze. 4. Késő középkori alapárkos épület 5. Árpád-kori kemencebokor 6-7. Gamás - Vadépusztai mező 1: 6. Árpád-kori ház 7. Középső rézkori körárok 
A kora bronzkori Somogyvár-Vinkovci kultúrából tárológödrök mellett nagyméretü agyagnyerő gödröket is feltártunk. Ez a telepmaradvány sem volt megfigyelhető a 67 . föút nyugati oldalán, csak hosszan a patak ártere mentén. Egy objektumot kell kiemelnünk, amelynek esetleges oszlophelyei tető meglétére utalhatnak. Változatos, viszonylag nagy mennyiségű mészbetétes díszkerámiát is tartalmazott.

A késő bronzkori Urnamezős kultúra gödrei föleg a 67. főúttól nyugatra sűrüsödtek, de elszórva attól keletre is előfordultak. Jellegzetes, nagy mennyiségü kerámiát tartalmaztak.

A 67. főúttól keletre egy kora Árpád-kori telep elszórt objektumait is kibontottuk, gödrök mellett három épületet, több külső kemencét. A házak nagyjából négyzet alaprajzúak, kis méretüek voltak, a kemencéjüket meghagyott agyagtömbbe vájták (IV. t. 6.). A 2018. évad eredményezte az Árpád-kori telep illusztris részét a lelőhely déli, erdő alatti végén. ${ }^{2}$

A feltárás munkatársai: Molnár István feltárást vezető régész, Somogyi Krisztina régész, Nyári Zsolt, Stunya Péter, Balla Krisztián, Cserép Tamás technikusok

\section{Gamás - Belső-tanya (93205) \\ Molnár István és Németh Péter Gergely}

A lelöhely a Tetves-patak és a Jazvina-tüskési vízfolyás által bezárt háromszögben emelkedő domb déli és nyugati lejtőjén található. Az igen gazdag lelőhelyet a többszöri terepbejárás ellenére sem sikerült előzetesen felderíteni, csak az útépítés földmunkái során került elő, részben a vastag földtakaró, részben vetéssel való fedettsége miatt.

A feltárás során számos régészeti korszak emlékeit sikerült megmenteni (V. t. 6.). A legkorábbi objektumok (több mint 20 gödör és 1 kemence) a Lengyeli kultúra időszakába tartoztak. A legtöbb lelet egy nagy, mély gödörből származik, mely nagyon sok festett edénytöredék mellett kőbaltát is megőrzött. Legalább egy gödör a rézkori Balaton-Lasinja kultúra időszakára keltezhető. A középső bronzkori Kisapostagi kultúra két, míg a késő bronzkori Urnamezős kultúra három gödrét azonosítottuk. Több objektum az őskoron belül pontosan nem keltezhető. A római kor 32 objektumához gödrök, cölöplyukak mellett egy félig földbe mélyített épület is tartozik. Szórványként számos érme és fémtárgy is a római kori telephez sorolható. Ugyancsak szórványként avar leleteket is találtunk, de a feltárás során népvándorlás kori sírok vagy települési objektumok nem kerültek elő

A területet a kora Árpád-kortól a késő középkorig is lakták. A gödrök mellett egy kút, egy épület és egy több kemencés mühelygödör is az időszakba tartozik.

Résztvevők: Molnár István, Somogyi Krisztina, Honti Szilvia, Németh Péter Gergely régészek, Nyári Zsolt, Stunya Péter, Szabó Domán, Papp Zoltán technikusok

2 2018. május-júniusában tártuk fel a lelőhely déli, erdő alatt lévó részét a dombvonulat lábáig. A neolitikum és a késő bronzkor kivételével a többi őskori telep, eltérő fedettséggel, a lelőhely végéig megfigyelhető volt. Egy népvándorláskori objektum is előkerült, ami egykorú lehet a DNy felöl szomszédos ERD 32. lelöhely telepmaradványával.

\section{Gamás - Országúti Studenca (72173) \\ Honti Szilvia}

A lelöhely a Tetves árok nyugati oldalán emelkedő dombsor keleti lejtőjén, a gamási bekötőúttól északra található, a 67-es út csak a szélét érinti. Több részletben folyt itt feltárás, 2016-ban próbafeltárás az út keleti oldalán, 2017-ben és 2018-ban a nyugati oldalon, a korábbi bozótos fasor eltávolítása után. Az út keleti oldalán, a próbaszondákban, mindössze két objektum maradványai kerültek elő. A nyugati oldalon, ahol jelentős bevágással szélesítették az út nyomvonalát, két, egymástól 100 méterre levő csoportban, 25 objektumot tártunk fel. Az eredeti talajszintet igen vastag eróziós réteg borította, mely az út mellett elérte az 1-1,20 métert is, a jelenségeket a meglevő út szintjén lehetett csak megfigyelni. Árpád-kori és középkori gödröket és kemencéket tártunk fel mintegy $2000 \mathrm{~m}^{2}$-es felületen.

Résztvevők: Honti Szilvia, Somogyi Krisztina régészek, Nyári Zsolt, Szabó Domán, Papp Zoltán technikusok

\section{Somogybabod - Tetvesi mező (72033) \\ Molnár István és Somogyi Krisztina}

A lelőhely Somogybabodtól délre, a Tetves-patakba torkolló vízfolyástól északra húzódó észak-déli irányú dombsor keleti aljában, a mai 67-es úttól nyugatra található. Észak felé egy ma is erősen belvizes, mélyebb terület határolja le. Egykor a mélyedés jelentősebb lehetett, a déli területek időnként víz alá kerültek, az ekkor képződő rétegek néhol fedik az objektumokat.

A 2015-ben végzett próbafeltáráson (HONTI ET AL 2016, 266) és a 2017 szeptemberében folytatott megelőző feltáráson, összesen közel $1000 \mathrm{~m}^{2}$-es területen, egy kelta gödör mellett egy középkori falu objektumait tártuk fel.

A dombtető felé húzódó középkori település élete legalább a 11. században megkezdődött, amit a kora Árpád-kori kerámia mellett Aba Sámuel pénze is bizonyít (IV. t. 3.). A falu a 16. századig lakott volt, kései kerámiája és érmei alapján a török időszak alatt pusztulhatott el.

A lelőhely déli részén sürün egymást is felülrétegezve jelentkeznek az objektumok, északra az ott található mélyebb terület felé haladva elfogynak. A feltáráson öszszesen 91 régészeti jelenséget különítettünk el. A számos gödör mellett több külső kemencét (IV. t. 5.) és két épületet is találtunk. Az egyik épület sekélyebb, a másik mélyebben földbe mélyített, cölöplyukas-alapárkos szerkezetü, akár pince is lehetett (IV. t. 4.).

A lelőhelyen szép leletanyag, közte pénzek, övcsatok, gyürük, aranyozott bronz késvég került elő. ${ }^{3}$

Résztvevők: Molnár István, Somogyi Krisztina, Honti Szilvia, Németh Péter Gergely régészek, Nyári Zsolt, Stunya Péter, Szabó Domán, Papp Zoltán technikusok

3 2018-ban az említett vízfolyástól délre építés közbeni bontómunka során az Árpád-kori telep folytatását és késő középkori objektumokat illetve kultúrréteget figyeltünk meg a domb alján, a 67. számú föút $\mathrm{Ny}$-i oldalán 

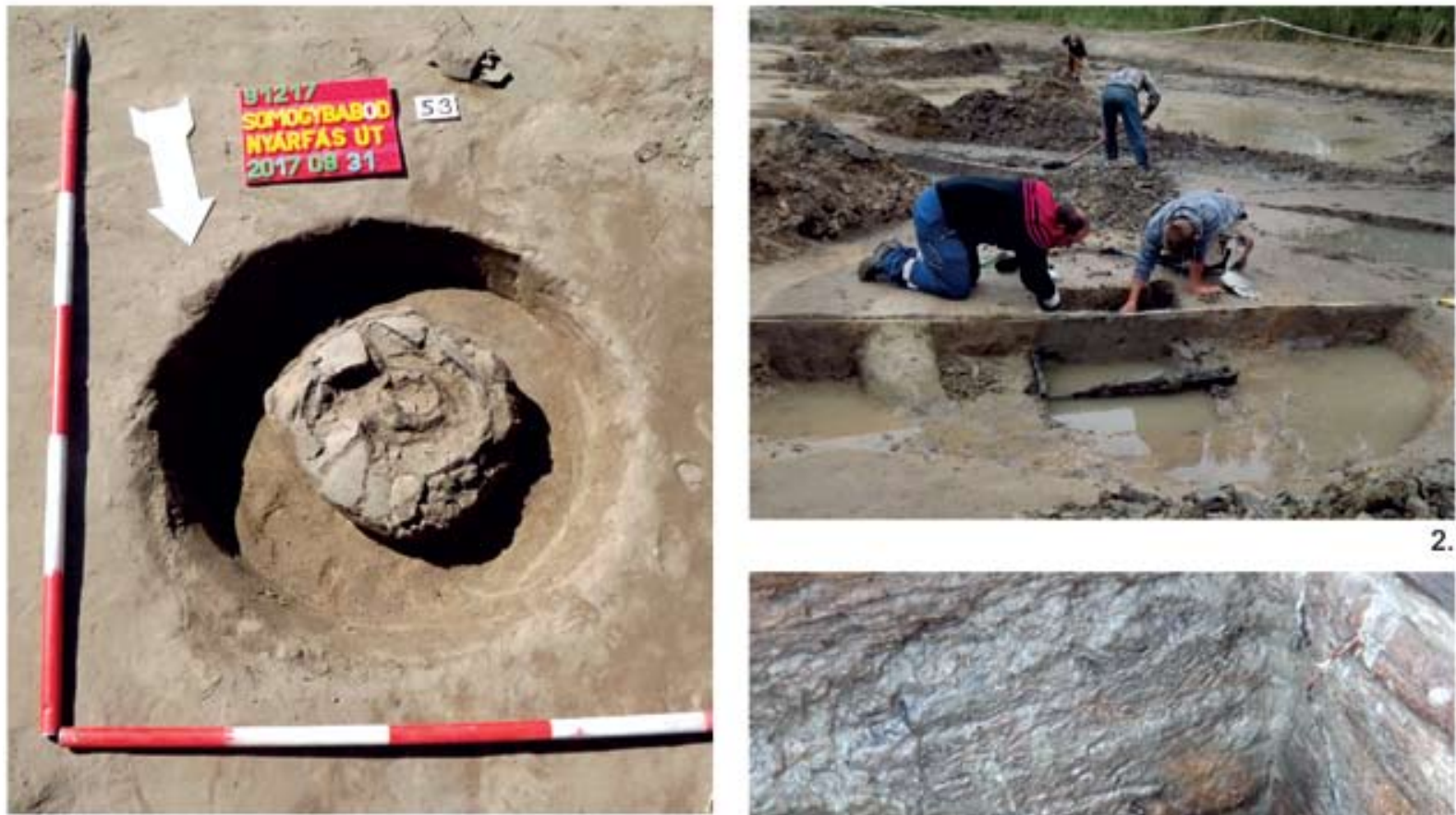

1.
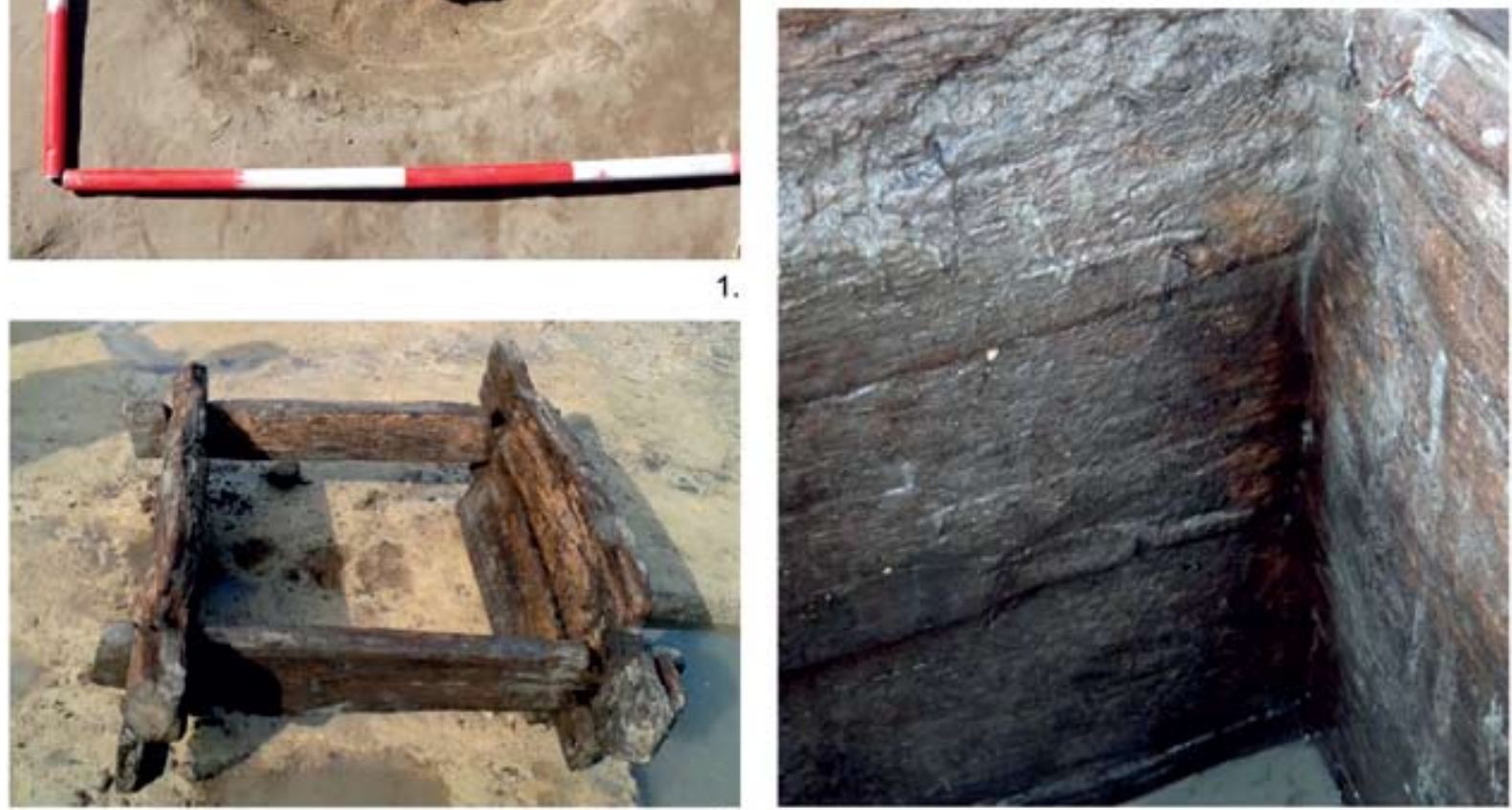

3.

4.
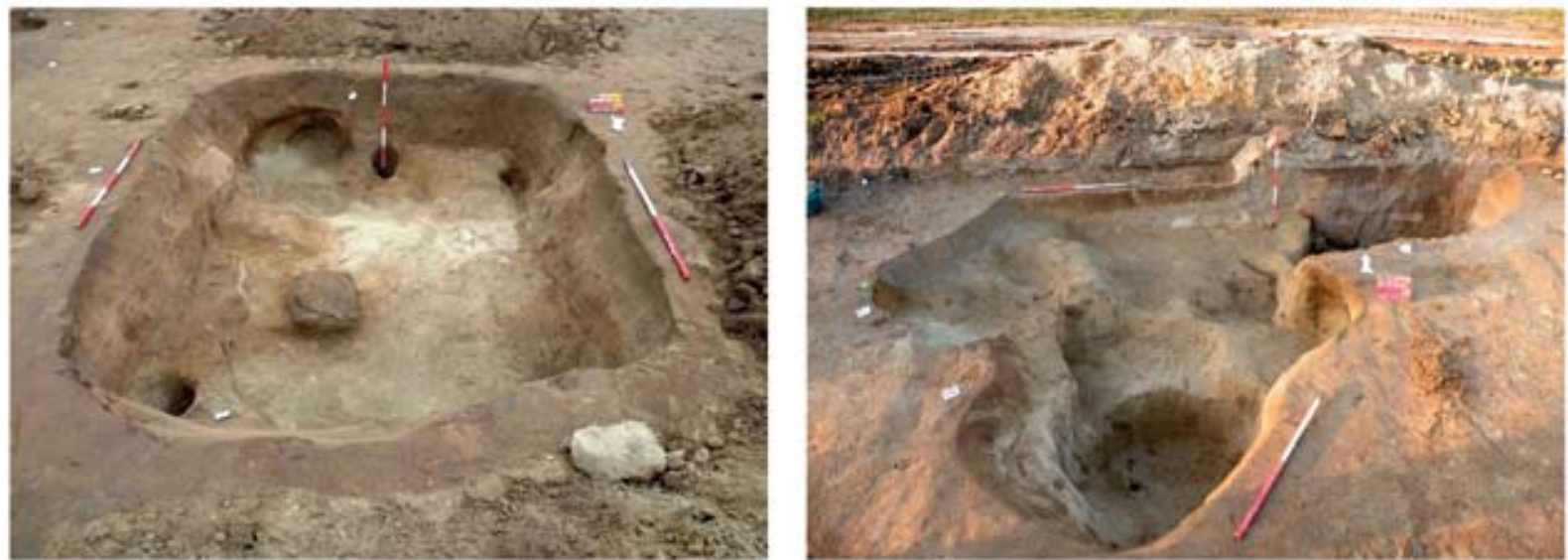

5.

V. tábla. 1. Somogybabod - Nyárfás-út, középső bronzkori urnasír maradványa. 2-4. Somogybabod - Tetves árok völgye: középkori kút feltárása és szerkezete. 5. Somogytúr-Buger-irtás: Árpád-kori ház belső kemencével. 6. Gamás - Belső-tanya: Római és középkori objektumok 


\author{
Somogybabod - Nyárfás-út (91217) \\ Németh Péter Gergely
}

A lelőhely a Kisbabodra vezető út mentén, Somogybabod déli széle és a Tetves-patak között található, közvetlenül a patak ártere feletti enyhe lejtőn, három oldalról mocsár övezi. A lelőhelynek az út melletti keskeny sávját lehetett csak feltárni, déli kiterjedését nem tudtuk lokalizálni. Néhány kelta települési objektum mellett egy kis középső bronzkori temetőrészlet került elő. Az erősen sérült urnasírok többségének csak az alja maradt meg, így csak az urna alját, a benne levő hamvakat, és néhány bögretöredéket lehetett csak megmenteni (V.t.1.).

Résztvevők: Németh Péter Gergely és Honti Szilvia régész, Balla Krisztián, Cserép Tamás technikusok.

\section{Somogybabod - Tetves-árok völgye (48062) Németh Péter Gergely}

A lelöhely Somogybabod keleti határában, a 67-es föút keleti oldalán, az út és a Tetves-árok között található, az 1967. évi terepbejárás során azonosították. A 2014. évi próbafeltáráskor során egy kelta objektum került elő, ugyanakkor a lelöhely déli részén nagyon sok késő középkori szórványlelet, ahol akkor a még itt álló fák miatt feltárást végezni nem lehetett. A 2017. évi feltárás a során kelta, Árpád-kori és késő középkori telepet tártunk fel. Megfigyeléseink alapján a lelöhely több kisebb homokdombon található, melyeket a Tetves-patak mocsaras ártere övezett a szabályozása előtt.

A kevés kelta objektum közé gödrök tartoztak, valamint kisebb, szabályos, sekély építmények, melyek mühelyek lehettek.

Az Árpád-kort kemencék és néhány települési objektum képviselte. A magasan lévő kemencék erősen szétszántottak voltak. Égetőterük alját széttört kerámiatöredékek alkották, melyet az egyiknél több rétegben alakítottak ki.

A legtöbb objektum a késő középkori telephez tartozott. Több, alapárkos és cölöplyukas építményt találtunk, melyeket néha egymásba ástak. Házak, esetleg részben mezőgazdasági jellegü épületek alapárkai lehettek. A magas talajvíz, mely a feltárást rendkívüli mértékben megnehezítette, egy esetben nekünk kedvezett: Feltártunk egy kutat, melynek cölöpszerkezetét a talajvíz remekül megörizte (V. t. 2-4.). Több faoszlop töredéke is épségben megmaradt, egy részük az objektumokban, de valószínübb, hogy nem régészeti korúak. $A$ késő középkori telep déli végén, két települési objektum területét érintve, legalább két emberi vázmaradvány került elő. A késő középkorba tartozhatnak, de nem zárható ki a későbbi keltezés sem.

A feltárás munkatársai: Németh Péter Gergely és Honti Szilvia régész, Balla Krisztián, Cserép Tamás, Papp Zoltán és Szabó Domán technikusok.
Somogytúr - Buger-irtás (91219)

Németh Péter Gergely és Honti Szilvia

A lelőhely a Tetves pataktól nyugatra, a patak árterének szélén emelkedő kis dombon található, Somogytúrtól délkeletre. Molnár István 2017. év eleji próbafeltárása alapján egy gyenge intenzitású lelőhelyre lehetett számítani, ezért kezdetben a tervezett utat kísérő, a lelőhelyet veszélyeztető vízlevezető árok nyomvonala került humuszolásra, melyben egy földbemélyített építmény részlete került felszínre. A feltárást ennek megfelelően a ház körzetében bővítettük, a $760 \mathrm{~m}^{2}$-es felületen a házon kívül egy sekély, de gazdag leletanyagú őskori objektum és néhány leletnélküli sekély jelenség került elő.

A ház szokatlanul kisméretü, nagyjából négyzetes alaprajzú, méretéhez képest meglepően mély, alja egyenetlen, három oldalon körben padkával. ADK-i sarkában, a déli falba vájva kisméretü, tapasztás nélküli kemence volt, előtte nagy, talán ülésre használt kővel. Három sarkában és a kemence mellett mély oszlophelyek voltak (V. t. 5.). A leletanyaga Árpád-kori kerámia, tapasztás-darabok, kevés állatcsont, ezek nem az alján, hanem a feljebb húzódó szürke (hamus) és barnás rétegben volt (15-40 cm között, a szelvényszinthez képest). Az alsó rétegben jobbára csak kődarabokat találtunk. Az építmény funkciója bizonytalan, ház vagy mühely lehetett, ám szokatlan, hogy csak magában áll. A feltárás munkatársai: Németh Péter Gergely és Honti Szilvia régész, Balla Krisztián, Cserép Tamás, Papp Zoltán és Szabó Domán technikusok.

\section{A 76-os út Balatonszentgyörgyöt elkerülő szakaszá- nak régészeti feltárásai}

Az R76-os út Somogy megyét érintő nyomvonala az M7 autópálya holládi lehajtójától indul, majd Balatonszentgyörgy - Battyánpusztát keletről kerüli el. Ez a vidék a Kis-Balaton keleti partján húzódó első átkelőhely, mely minden időben járható volt, a mocsaras part és a Barihegy között, minden időben használt út és lakott hely volt. Ezen a régészeti lelöhelyek három kilométer hosszan, lényegében megszakítás nélkül sorakoznak egymás után (VI. t. 1.). A 2016 őszén végezett próbafeltárások után 2017 késő tavaszán kezdődtek meg a teljes felületü feltárások 4 lelöhelyen, összesen több mint $120.000 \mathrm{~m}^{2}$-en. A legészakibb rész kivételével a Rippl-Rónai Múzeum végezte az útépítést megelőző feltárásokat 2017-ben, a projekt szakmai koordinációját pedig a Budavári Kft. Az északi lelőhelyen a Magyar Nemzeti Múzeum dolgozott.

\section{Balatonszentgyörgy - Kocsmaházi-dülő IV Füköh Dániel}

A lelőhely a Kis-Balaton környékére jellemző domborzati viszonyokkal rendelkezik. É-ról D-felé haladva a tengerszint feletti magasság enyhén emelkedik. Nagyjából a lelőhely közepén az 572 és az 570 kitüzési pont között egy csatorna és a 090/1 (090/2) számú földút vágta ketté a feltárás területét. A lelőhely alacsonyab- 

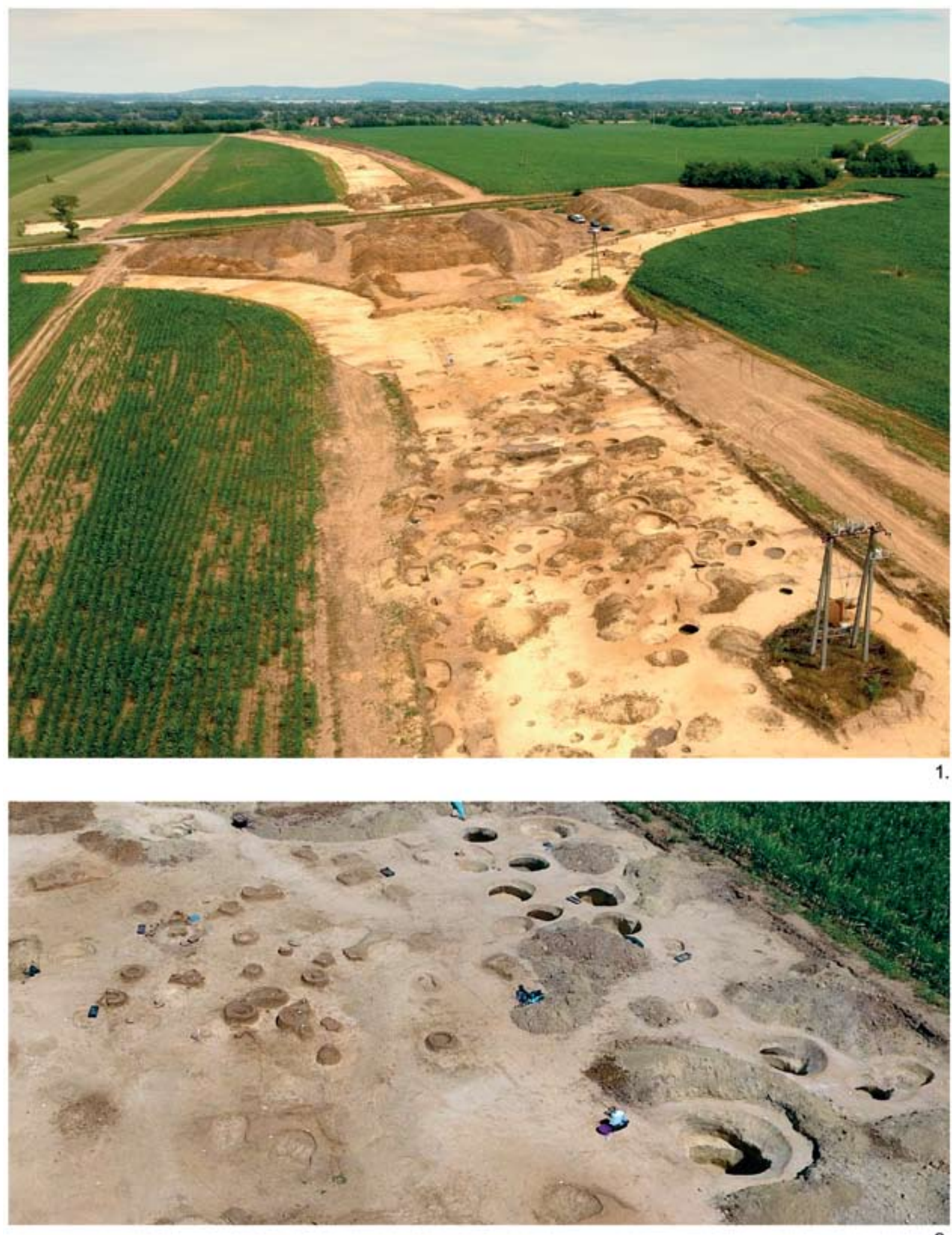
ban fekvő É-i részét Ny-ról és É-ról egyaránt egy kiemelkedés határolja, a K-i oldalon Balatonszentgyörgy belterülete húzódik. A talajtani jellemzők kettős képet mutatnak. A lelőhely É-i részén jégkori agyagra vastag sötétszínü humuszréteg rakódott, melyben nagy menynyiségben vannak jelen lápos környezetre utaló puhatestü fajok maradványai (FüKöH 2001). A sárga színű, szürke foltos, vaskiválásos agyagrétegeket a jégkorszaki glaciális periódusokban képződött aprókavicsos rétegek választják el (BRADÁK 2007). A lelőhelyen belül D-felé haladva, a humuszréteg puhatestü maradvány tartalma csökken, ez szárazabb környezetre utal. A feltárás magasabban fekvő déli területét, löszös altalajra rakódott, vékony, világosbarna, gyenge minőségű humuszréteg jellemzi.

A legfiatalabb objektumok az Árpád-korból származnak. Egy cölöpszerkezetes, féltetőszerü építményben kavics alapozású kisméretü kerek tüzhely, a humuszolt felszínen jelentkező vöröses színü, átégett omladék rétegek, melyek az őskori objektumok szintje felett 15-20 cm-rel kerültek elő, és egy kasos szerkezetű, vesszőfonattal bélelt kút tartoznak ide. A déli feltárási területen került elő két, szintén Árpád-kori gödör, melyek közül az egyik egy rézkori gödörre volt ásva.

A bronzkor középső szakaszának végéhez tartozott az a Koszideri horizontból származó gödör melyből egy kerek, ónozott bronzcsüngő került elő. Az ehhez hasonló bordás tutulusok a korszak kedvelt ékszerei, és - gyakran tüskével ellátva, - a halomsíros kultúrában is elöfordulnak még (TROGMAYER 1969). Egy másik, hasonló korú objektumban bronz poncoló tüt találtunk. Feltártunk még 7 kora bronzkorból származó, méhkasos metszetü, rétegzett betöltésü, kerek gödröt, melyekböl fésüs, illetve sürü párhuzamos bekarcolt vonalköteg díszítésü, nagyméretű tárolóedény töredékei, kisebb, gömbös testű korsó töredékei és kisméretű, kónikus testű bögrék töredékei kerültek elő. Seprüzéssel felületkezelt, vagy simított, enyhén fényezett felületű töredékekkel együtt. A leletanyag alapján a gödröket a Somogyvár-Vinkovci kultúrához sorolhatjuk (BoNDÁR 2001).

$A z$ objektumok jelentős része a rézkor különböző korszakaiból származik. A Badeni kultúrát nagyméretű, homogén betöltésü gödrök és egy gödörbe temetett emberi váz jellemzi, melynek melléklete ugyan nem volt, de a váz felett $30 \mathrm{~cm}$-rel vastag kerámiaréteget találtunk, ami halotti tor, vagy áldozat maradványa lehetett. (VII. t. 6.) A Badeni kultúrához köthető egy gödörbe rendellenesen temetett emberi váz, melynek mellékleteként volt értelmezhető a mellé helyezett szarvasmarha koponya és egyéb csontok. Egy másik gödörböl emberi koponya és állkapocs töredékei kerültek elő, további vázrészek nélkül. Az edények között a fényezett felületü, samottos vagy homokos soványítású, bekarcolt vonalakkal díszített, jól égetett, vékony falú lapos tálak, peremből induló, felhúzott fülű bögrék jellemzik. Egy újabb gödörből agyagkanál, idoltöredék és egy ismeretlen eszköz agyagból formázott markolata került elő (VII. t. 2.). A rézkor e szakaszát további homogén betöltésű gödrök képviselik, valamint két nagyméretü, szabálytalan alakú, több beásásból álló, sekély gödör, amelyek szélén, illetve sarkában találtunk cölöphelyeket. Ezeket épületként, építményként is értelmezhetjük, bár tűzhely, vagy égetés nyoma egyikböl sem került elő. Földfelszín fölé épült, illetve oszlopokon álló épületek nyomára utalnak az elszórtan jelentkező oszlophelyek is (HORVÁTH-GHERDÁN-HERBICH-VASÁROS 2005). A Badeni kultúra korai szakaszát, a Boleráz csoportot a lelőhely északi részén előkerült gödrök és oszlopszerkezetes házak maradványai képviselik. Ebből a korszakból gyengén égetett, durva, aprókavicsos soványítású, bevagdosott peremű, ívelt oldalú nagyméretű edények töredékekei a jellemzőek, gyakori az ujjbenyomkodásos vízszintes bordadísz. Megfigyelhető volt, hogy ezek az objektumok a Balaton partjához közelebbi területen helyezkedtek el, a Badeni kultúra későbbi szakaszának objektumai észak felé sürüsödtek. Ez a Balaton vízszintjének változásaival lehet összefüggésben (HORVÁTH-SVINGOR-MOLNÁR 2006). A korszakhoz tartozó gödrök közül kiemelkedik egy sekély, ovális alakú, melyből nagymennyiségü kagylóhéj került elő, mely egy fajhoz (Unio Pictorum) tartozik. Ez a kagyló gyakran kerül elő a térség régészeti lelöhelyein (FüKÖH 2001). A lelöhely legidősebb objektumai a rézkori Balaton-Lasinja kultúrához köthetők. Ebből a korszakból, egy körülbelül $7 \times 15$ m alaprajzú, alapárkos, oszlopszerkezetes ház került elő (VII. t. 5., KISS-RÉTI 2005). Az épület alapját, egy nagyjából $\mathrm{K}-\mathrm{Ny}$-i irányú, téglalap alakú árokrendszer alkotja. A ház alapozása 2 árokból áll, melyek több helyen nyitottak. A kéthelyiséges ház középen osztófallal volt ellátva, középen átjáróval. Mind az északi mind pedig a déli oldalán az árok megszakad, elképzelhető tehát, hogy két bejárata is volt. Az épület középső oszlopsora 3 nagyméretű cölöphelyböl áll. Ez ágasfás, szelemenes tetőszerkezetre utal. A ház felmenő fala sövényfonatos, paticsos szerkezetű lehetett. A középső cölöphelyéből erősen égett rétegből, nagy mennyiségü, világosbarna, homokkal soványított, szendvicses törésfelületü, durva felületű, díszítetlen, edénytöredékek, és nagymennyiségü patics került elö (VII. t. 6.). Az egyik hasonló korú gödörből nyéllyukas kőbalta, valamint trapéz alakú kővéső töredékei kerültek elő. A lelőhelyen több kőbalta töredéket is találtunk, ezek közül kiemelkedik egy zöld szerpentinitböl csiszolt, nyéllyukas töredék (VII. t. 3.). Pattintott kőeszközök nagy számban kerültek elő a lelőhelyen. Ennek túlnyomó része radiolaritból készült penge vagy vakaró. Kisebb számban előfordult szürke kova illetve kvarc. Egy kiemelkedő lelet kapcsolható még ide: egy gyengén kiégetett, kézzel gyúrt agyaggombócból három kőeszköz került elő.

Összegezve, a lelőhelyen 8 Árpád-kori objektum mellett több különféle őskori megtelepedés nyomait sikerült kimutatni. Az őskori telepek jellegzetes nyomai (gödrök, oszlophelyek) mellett sikerült egy alapárkos Balaton-Lasinja kultúrához tartozó épület maradványait feltárni. Ez az épület a magasabban fekvő, szárazabb, löszös területen került elö, az északi lápos, agyagos területen feltárt cölöphely sorok alapján, minden bizonynyal cölöpökön álló házakat építhettek, melyek jobb védelmet nyújtottak a változó talajvízszinttel szemben. 


\section{Balatonszentgyörgy - Faluvégi-dülő 2. (54716) Molnár István és Somogyi Krisztina}

A lelőhely a battyánpusztai bekötőúttól a téglagyárhoz vezető, 75101. számú aszfaltút két oldalán, a Kígyós-árok keleti partján található. Feltárását 2017. május 31. és július 25 . között végeztük, $45599 \mathrm{~m}^{2}$ nagyságú terület volt objektumokkal fedett (VI. t. 1).

A legkorábbi objektumok a Lengyeli kultúra időszakára keltezhetőek, amelyek a szomszédos Balatonszentgyörgy-Szent-kút lelöhely lengyeli településének északi végét képezik. A telepet egy nagyméretű, „V” átmetszetű kerítőárok zárta le, (VII. t. 7.) amelynek egy-egy szakasza mindkét lelöhelyen megfigyelhető volt. A gödrök egy része a leletanyag, másik része a betöltés alapján sorolható ehhez a korszakhoz. Fontos eredmény, hogy a megyében eddig ismert kevés számú sír egy újabbal gyarapodott, ugyanis sikerült feltárnunk a Lengyeli kultúra egy temetkezését. A sír NyÉNy-KÉK-i tájolású. $A z$ ovális sírgödörbe jobb oldalán zsugorított pozícióba egy felnőtt személyt fektettek. A karok környezetébe egy kis méretü, tagolatlan, enyhén $S$ profilú edénykét és egy vörös festett, két sorban kis bütykökkel díszített poharat helyeztek (VII. t. 8.).

A középső rézkori Balaton-Lasinja-kultúra települése a lelőhely általunk feltárt északi végében volt jelen, észak felé folytatódik tovább a szomszédos feltárás, a Kocsmaházi-dűlő IV lelőhely eredményei alapján.

A Baden kultúra gödreit a lelöhely északi részén tártuk fel. Kutatástörténeti jelentőségü, hogy a megyében elsőként került elő a Badeni kultúra vegyes rítusú temetője (VI. t. 2., VIII. t. 2.). Sajnos a sírok fölött vékony rétegben maradt meg a talaj, emiatt többségük sérült. Összesen 69 önálló temetkezés, valamint három kettős sír (VIII. t. 4.) került elő, ez utóbbiak közül a két gyermeksír esetében ez nem teljesen biztos. Az egyértelmüen meghatározható rítusúak közül zsugorított csontvázas 31, urnás 17 és szórt hamvas 7 sír volt. 11 sírmaradvány jellege bizonytalan, 8 hamvasztásos sír mellett 6 sírban nem maradtak meg a csontok (csak kerámiatöredékek vagy kő jelezte az elpusztult sírt). A jellegzetes tájolás a csontvázas rítusban a dél-észa$\mathrm{ki}$, de ettől eltérő esetek is voltak. Fontos adat, hogy 10 esetben (7 csontvázas és 3 hamvasztásos rítusú) megfigyeltük a sírokra tett ún. kőpakolás köveit is, amelyek kevés darabból álltak (ellentétben pl. Pilismarót sírjaival.). 3 csontvázas sírnál az újkori vagy régészeti korú bolygatás miatt nem voltak eredeti helyükön a kövek. Egy esetben maradt meg a kőpakolás teljesen (780. str., VIII. t. 1.). A csecsemő- vagy gyermeksírokban az erősen zsugorított helyzetü holttestet egyetlen, nagyobb, hosszúkás kővel fedték be. A sírokban a kevés számú edénymelléklet mellett gyöngyök (VIII. t. 3.), 1-2 orsógomb, egy esetben okker fordult elö. A 779. szórt hamvas sírban egy réztárgy (lemeztöredék) is volt. $A z$ edénymelléklet száma bármelyik rítus esetén maximálisan 4 darab, amelyekre jobbára töredékek utaltak (és csak a restaurálás során voltak dokumentálhatók), elhelyezkedésük sem volt egyértelmüen meghatározható. Jellemző az urnának (ami általában amfóra típus vagy fazékféle) tállal való lefedése. A kisebb edény(ek) lehet(nek) az urnában, vagy azon kívül is. Orsógombot urnába helyezve találtunk. A szórt hamvas sírok a hamvak köré tett edényekkel vagy edénnyel lefedve kerültek elő, de megmaradt edénytöredék nélkül is előfordultak. Az edényformák közül gyakori a magasra húzott fülü kisés nagyméretű korsó, a füles bögre és a bikónikus tálak törésvonalukon bemélyítés-sorral.

A temető körüli, pontosabban a temető területének nyugati és keleti sávjában lévő gödrökben több gödörbe tett tetemet is feltártunk. Egy esetben elhelyezett (azaz „rendesen” eltemetett), két esetben valószínüleg bedobott vagy szokatlan, nem szabályos pozícióban volt a csontváz. A sírok, föleg a hamvasztásos sírok nagy része magasan, még a humuszréteg alatti talajrétegben helyezkedett el, ezért a temető ún. központi részét egy nagyobb kiterjedésben meghagyott tömbből ásónyomos módszerrel bontottuk ki. A temető északi és déli széle lehatárolható volt, a másik két irányban a feltárási határon túl is folytatódhat.

A lelőhelyen talált őskori objektumok többsége a kora bronzkorra keltezhető, kevesebb a SomogyvárVinkovci kultúra, több a Kisapostagi kultúra időszakába tartozó. A Somogyvár-Vinkovci kultúra gödrei az északi felületen vannak elszórva, és észak felé folytatódnak tovább a következő ásatási felületen. De a Téglagyári úttól délre is voltak még telepjelenségek, köztük egy nagy anyagnyerő gödör, amelyben 3 egymásra tett szarvasmarhatetem feküdt.

A Kisapostagi kultúra objektumai a lelöhely déli részén csoportosulnak, összességében közel 300 m hoszszan húzódott a közel 100 települési egység. Az általunk feltárt telep a legnagyobb objektumszámú és kiterjedésű településmaradványok közé tartozik Somogy megyében! Több nagyméretű (20-30 méter átmérőjü) agyagnyerő mellett számos kisebb-nagyobb gödröt, közte több méhkas alakú tárolóvermet és egy, kuriózumot jelentő épületet tártunk fel a korszakból. A földbemélyített építmény gödrének szélén több oszlophelyet figyeltünk meg. Az építmény mellett közvetlenül két verem helyezkedett el, amelyeket talán egy időben használtak az épülettel (VII. t. 9.). A vermek nagy mennyiségü szenült növénymaradványt tartalmaztak. Épületek meglétére utal a nagy mennyiségü paticstöredék is. Megemlítendő a telep nagymennyiségü megmunkált kőanyaga (elsősorban őrlőkövek).

A település mellett ennek az időszaknak a sírjait is megtaláltuk. A DK-i lehajtóban, közel 50 méter hoszszan, északkeletről dél felé kanyarodó ívelt vonalon egy birituális temető 3 urnasírját és 6 zsugorított temetkezését tártuk fel. A sekély sírokat roncsolta a szántás, több sír teljesen elpusztult. Egy másodlagos helyzetű bronz kar- vagy lábperecet találtunk csak a csontvázas sírokban. A temető nyugati és keleti irányban folytatódhat.

A római kori telepmaradvány is jelentős eredményeket hozott, számos gazdag leletanyagot tartalmazó gödröt, tárolóvermet és épületet tártunk fel. A nagy számú, összesen 19 épület között volt 2, 4, 6 és 8 oszlopos is. Többször megfigyeltük a tapasztott padlót, de tüzelöberendezés nem volt bennük, az egyikben egy 


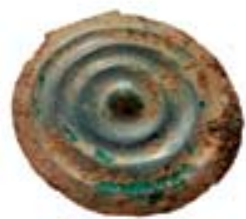

1.
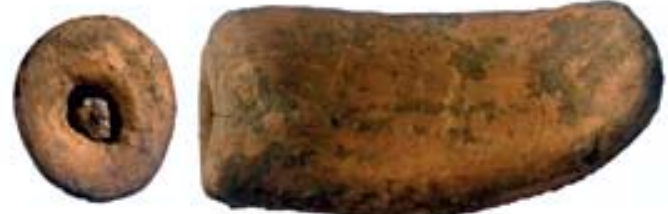

2.

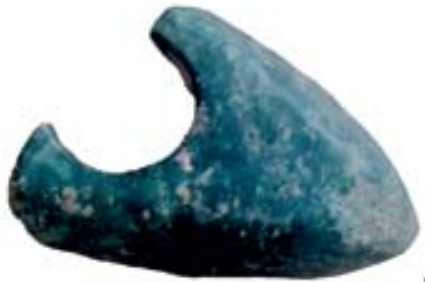

3.
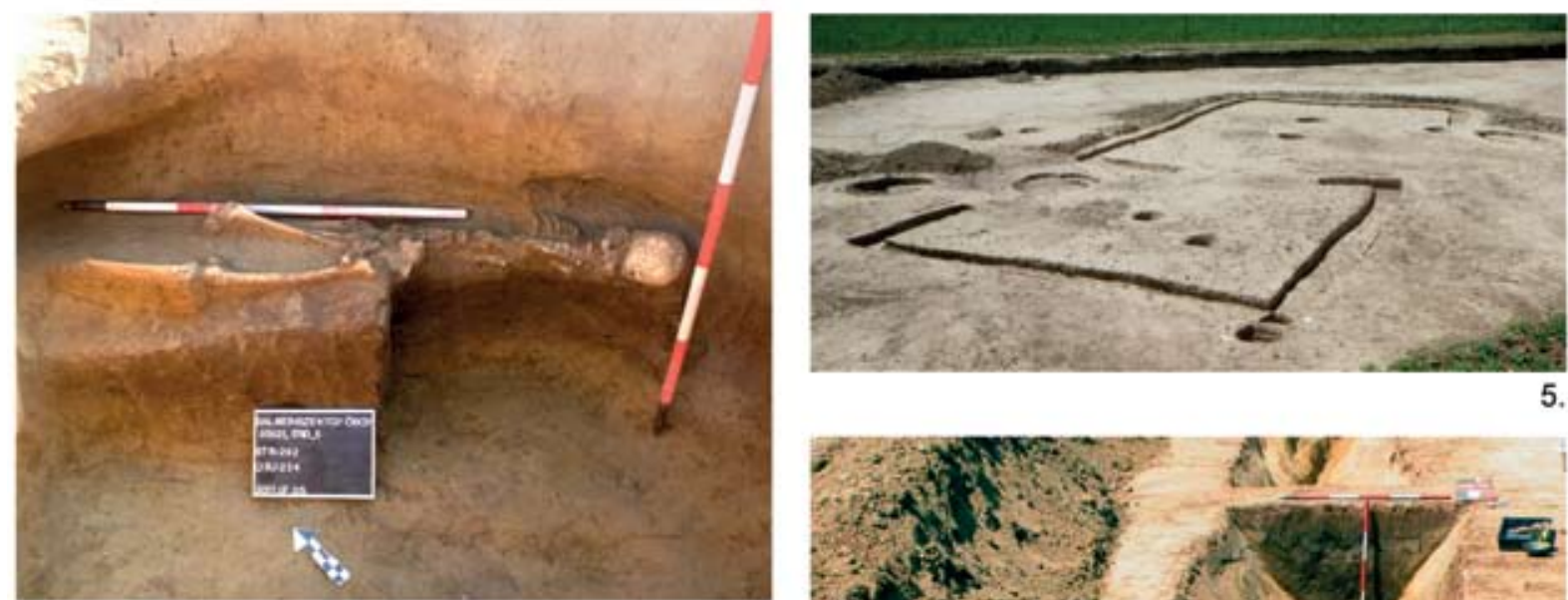

5.

4.
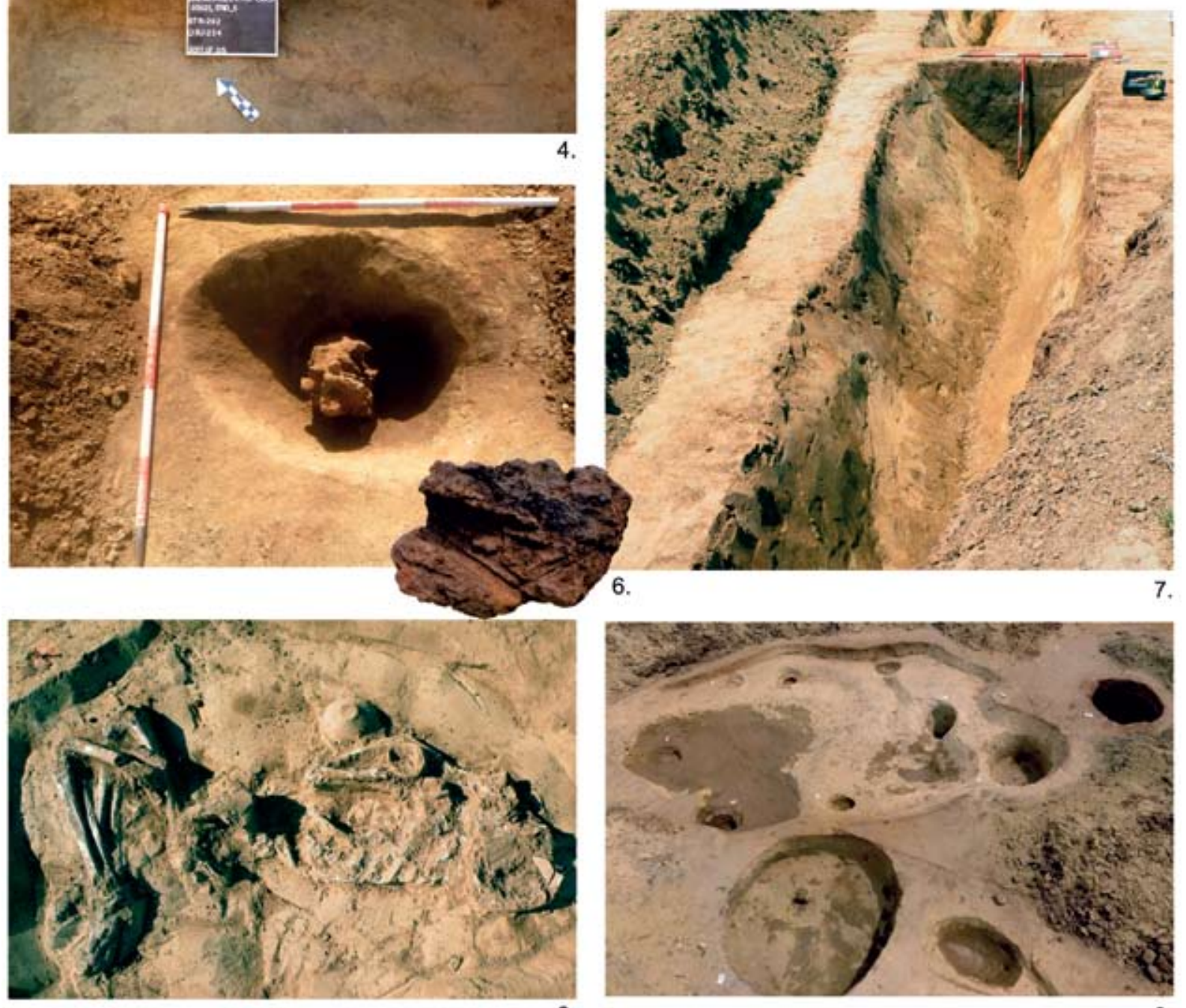

8.

VII. tábla. 1-6. Balatonszengyörgy - Kocsmaházi-dülö IV: 1. Bronzkori korongcsüngő. 2. Agyagtárgy. 3. Köbalta töredéke 4. Áldozati temetkezés 5-6. Középső rézkori alapárkos ház, és a közepén levő, égett anyaggal teli gödör. 7-9. Balatonszentgyörgy - Faluvégi-dülö 2: 7-8. A lengyeli kultúra körárka (690.str.) és edénymellékletes sírja (707. str.) 9. Kisapostagi építmény vermekkel 

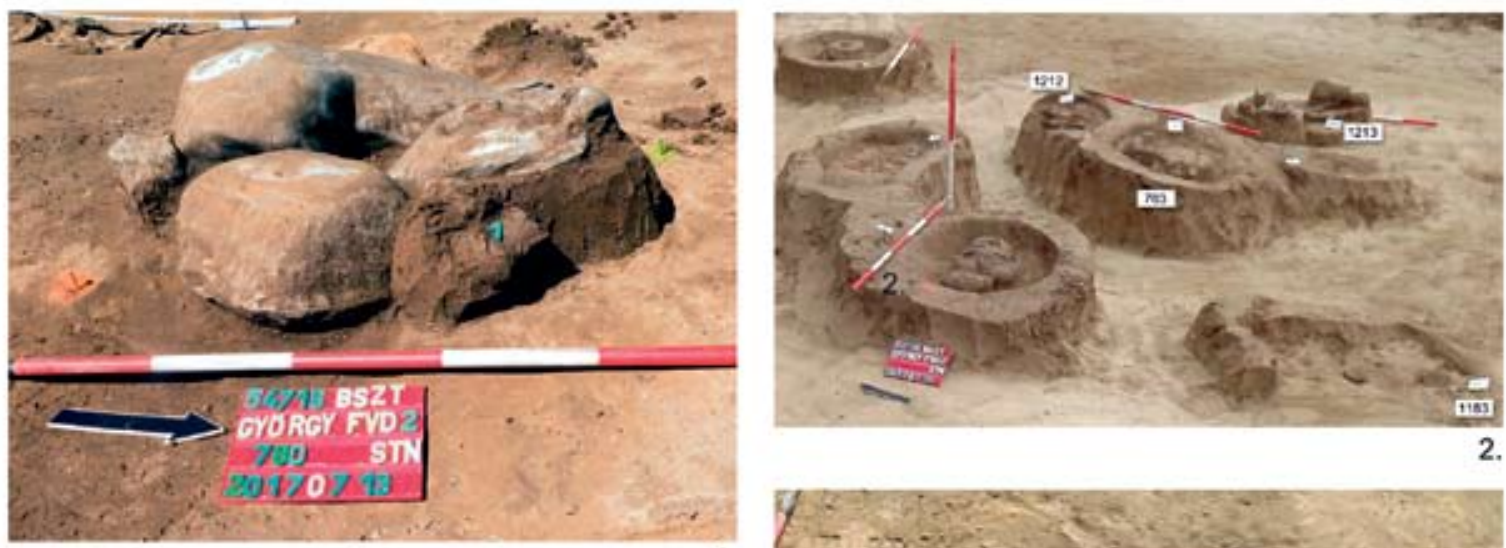

2.

1.
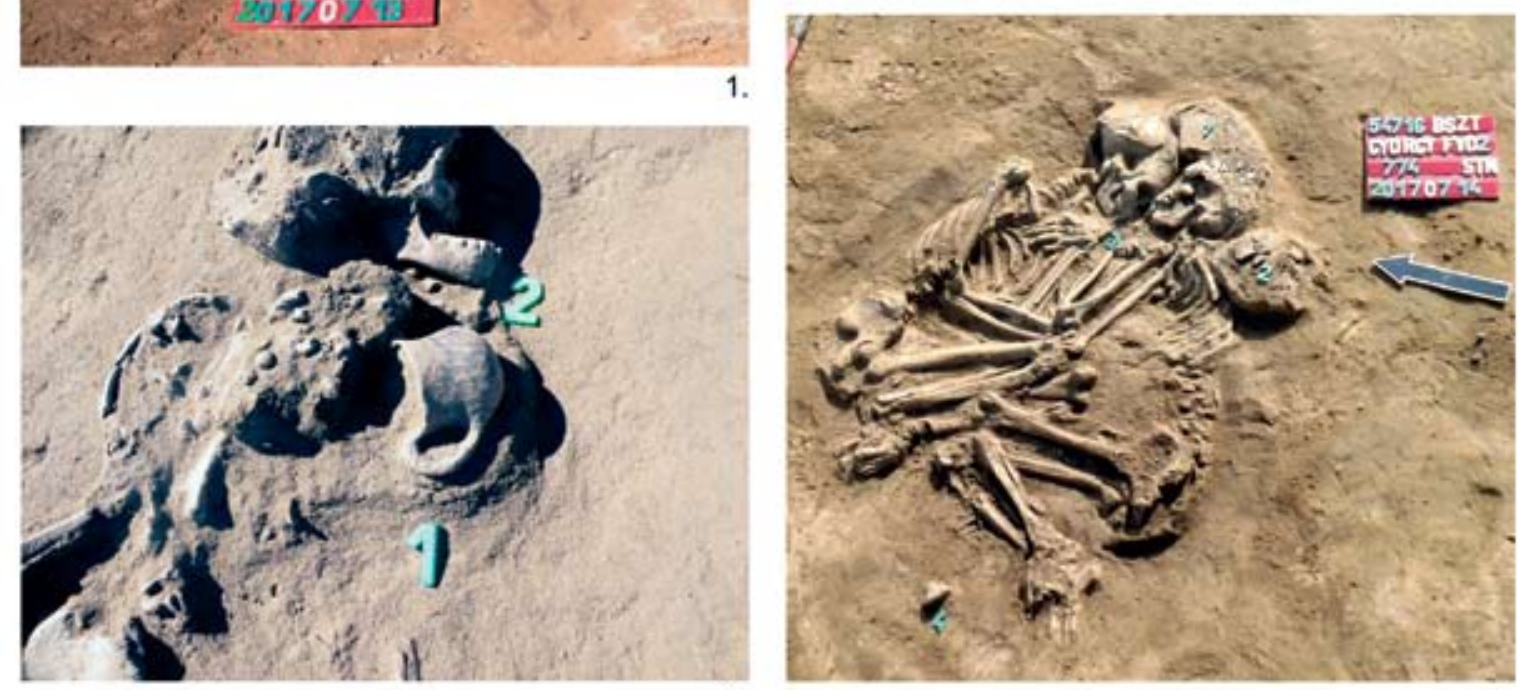

3.

4.
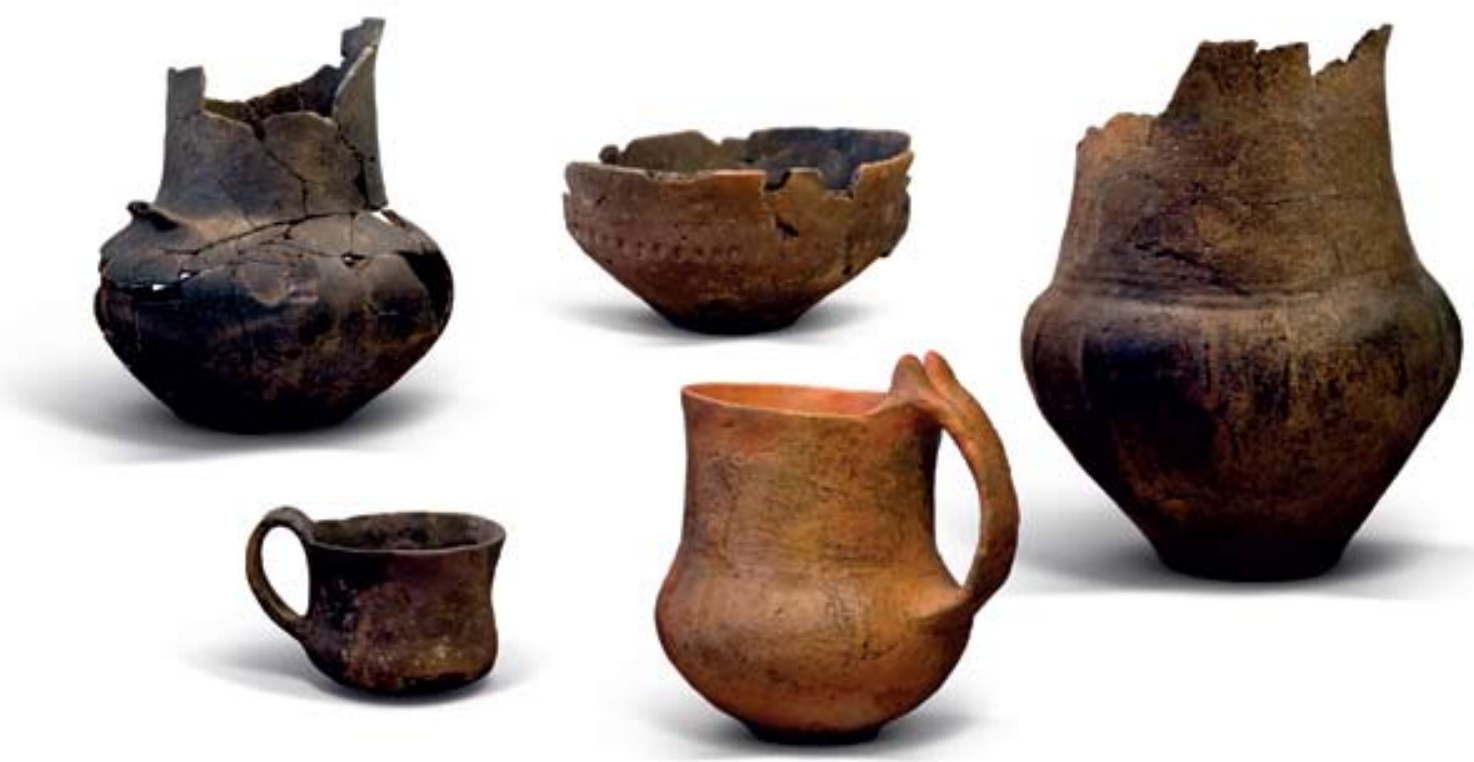

5.

VIII. tábla. Balatonszentgyörgy - Faluvégi dülö 2, a Badeni kultúra birituális sírjai és sírkerámiája: 1. Köpakolásos sír, 780. str. 2. Sírcsoport. 3. Az 1211. sír edénnyel és gyöngyökkel. 4. A 774. kettös sír. 5. Urnák, tál, kisbögre és korsó a temetkezési mellékletekből 
kupacban agyagnehezékeket találtunk. A nagyszámú kerámiatöredék mellett értékes fémanyagot, közte fibulát, mérleget, érmeket is találtunk. A római kori telep, a lelőhely északi és déli vége kivételével, a teljes feltárt felületen meglehetősen szórtan volt megfigyelhető.

A kora Árpád-kortól a késő középkorig tartó időszakból 6 félig földbe mélyített épületet, tucatnyi kemencét, egy kutat és számos gödröt tártunk fel. A korai objektumok (közel 50) csoportokban elszórva gyakorlatilag az egész lelőhelyen előfordulnak, a 13-15. századi épületek, gödrök egy csoportban, a DK-i lehajtó keleti végében sürüsödtek.

A feltárás munkatársai: Molnár István és Somogyi Krisztina régészek, Nyári Zsolt, Stunya Péter, Cserép Tamás, Balla Krisztián és Papp Zoltán technikusok

\section{Balatonszentgyörgy - Szent-kút Németh Péter Gergely}

A lelöhely a Balatonszentgyörgyhöz tartozó Battyánpuszta délkeleti végénél, a Kígyós-árok (Battyáni-patak) forrásvidékének két oldalán található. A lelőhely területén 2006-ban, 2013-ban és 2016-ban is végeztek terepbejárást. A 2016 évi próbafeltárás után, 2017-ben, a megelőző feltárás során, $8453 \mathrm{~m}^{2}$ nagyságú területet tártunk fel. A Kígyós-árok korábbi vízfolyásai tagolták a lelőhelyet, feltételezésünk szerint az árok eredetileg szabálytalan mederben, a mostani helyétől keletre folyt. A bolygatottság nem volt jelentős, bár több jelenkori gödör is előkerült. 56 régészeti objektumot tártunk fel, az őskort a Lengyeli kultúra 29 települési objektuma, a többi régészeti jelenség az Árpád-korhoz tartozott.

A Lengyeli kultúra legjelentősebb objektuma egy nagykiterjedésü, de sekélyebb árok volt, a patak nyugati oldalán. Kisebb szakaszát megtaláltuk a túlparton is, míg a szomszédos ásatáson (Faluvégi-dűlő 2. lelőhely) is elő- került egy újabb, nagyobb részlete. Az őskori telepet nyugatról lezáró árokból számos kerámiatöredék került elő, így füles edények töredékei, csőtalpas táltöredék és átfúrt agyagtárgy is. A telepen belüli objektumokban kevés leletanyag volt, de az árok melletti nagyobb gödrökböl sok leletet gyűjtöttünk. Előkerült egy ép, bütykös kisedény ( 2 . ábra), egy „miniatür” edényke, szürőedény aljtöredéke, egy hengeres agyagtárgy. Több festett edénytöredéket is találtunk valamint sok kovapattintékot és köeszközt.
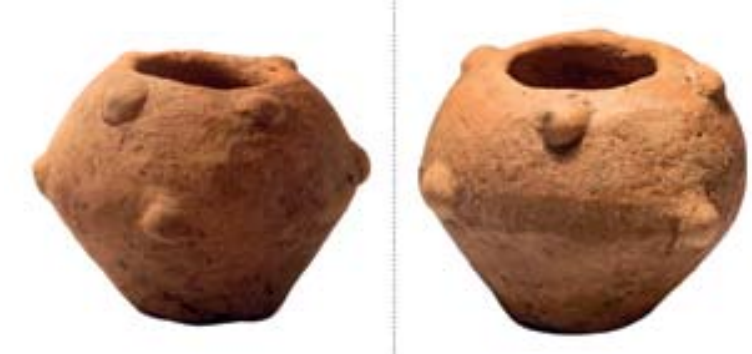

2. ábra. Balatonszentgyörgy - Szentkút: A Lengyeli kultúra edénykéje a 15. objektumból

Az Árpád-kori telep objektumai a lelőhely délnyugati részén, nagy területen elszórva kerültek elő. Több objektumot a magas talajvíz miatt nem tudtunk feltárni, kérdéses, hogy eredetileg, a mélyebb gödrök kiásását egyáltalán be tudták-e fejezni. Ebből a korszakból említést érdemel egy magasan lévő kemence, melynek alját kerámiatöredékekkel rakták ki és egy ízben megújították. A gödrökből fazéktöredékek mellett kevés fémtárgy és állatcsont került elö.

Feltártunk egy ovális, ívelt falú, teknős aljú, erősen átégett gödröt is, alján vastag faszénréteg volt. Leletanyag nem került elő, így nem eldönthető, hogy az őskori, vagy az Árpád-kori telephez tartozott-e.

\section{Irodalom}

ARADI Cs. és MoLNÁR I. 2017: Premontrei prépostság feltárása Bárdudvarnok határában. Várak, kastélyok, templomok 2017. évkönyv: 58-62.

BONDÁR M. 2001: Adatok a Délnyugat-Dunántúl korabronzkori kutatási problémáihoz. - Zalai Múzeum 10: 67-79.

BRADÁK B. 2007: Öskörnyezet-rekonstrukció Vörs Máriasszonysziget régészeti lelöhely környezetében - Szedimentológiai és Paleotalajtani közelítés. - Archeometriai Mühely (2007/1): 6776.

FüKöH L. 2001: Kvartermalakológiai vizsgálatok a Kis-Balaton II. víztározó területén. - Folia Historico Naturalia Musei Matraiensis 25: $25-40$.

Hontı Sz., Arad Cs., Balogh Cs., György L., Költő L., MolnáR I., NÉmeth P. G., SKRIBA-NAgy M., SOMOgYI K. ÉS TOKal Z. M. 2016: Régészeti kutatások Somogy megyében 2012-2015 között. A Kaposvári Rippl-Rónai Múzeum Közleményei 4: 247286
Horváth T., GHerdán K., Herbich K., és VAsáros Zs. 2005: Häuser der Badener Kultur am Fundort Balatonőszöd-Temetői-dülö. Acta Archaeologica Hungarica 58 (2007): 43-105.

HoRvÁTH T., SVINGor É. és MOLNÁR M. 2006: Újabb adatok a BadenPéceli kultúra keltezéséhez. - Archaeometriai Mühely (2006/3): 19-30

KISS V. és RÉTI Zs. 2005: Középső rézkori alapárkos ház Zamárdiból (Háromdimenziós számítógépes grafika alkalmazásának lehetőségei) - Ősrégészeti Levelek 7: 74-90.

TROGMAYER O. 1969: Középbronzkori leletek Kömpöcröl Móra Ferenc Múzeum Évkönyve 1969/1: 87-96 